\title{
Precision Agriculture Technologies Positively Contributing to GHG Emissions Mitigation, Farm Productivity and Economics
}

\author{
Athanasios Balafoutis ${ }^{1}$, Bert Beck ${ }^{2}$, Spyros Fountas ${ }^{1}$, Jurgen Vangeyte ${ }^{2}$, Tamme van der Wal ${ }^{3}$, \\ Iria Soto ${ }^{4, *}$ (D), Manuel Gómez-Barbero ${ }^{4}$, Andrew Barnes ${ }^{5}$ (D) and Vera Eory ${ }^{5}$ \\ 1 Agricultural University of Athens, Iera Odos 75, 11855 Athina, Greece; abalafoutis@aua.gr (A.B.); \\ sfountas@aua.gr (S.F.) \\ 2 Institute for Agriculture, Fisheries and Food research (ILVO), Burgemeester Van Gansberghelaan 92 box 1, \\ 9820 Merelbeke, Belgium; b.beck@ilvo.vlaanderen.be (B.B.); Jurgen.Vangeyte@ilvo.vlaanderen.be (J.V.) \\ 3 Wageningen Environmental Research (Alterra), P.O. Box 47, 6700 AA Wageningen, The Netherlands; \\ tamme.vanderwal@wur.nl \\ 4 European Commission, Joint Research Centre (JRC), Directorate Sustainable Resources, \\ Economics of Agriculture, Edificio Expo, Calle Inca Garcilaso 3, E-41092 Seville, Spain; \\ Manuel.GOMEZ-BARBERO@ec.europa.eu \\ 5 Scotland's Rural College, Peter Wilson Building, Kings Buildings, West Mains Road, \\ Edinburgh EH9 3JG, UK; Andrew.Barnes@sruc.ac.uk (A.B.); Vera.Eory@sruc.ac.uk (V.E.) \\ * Correspondence: Iria.SOTO-EMBODAS@ec.europa.eu; Tel.: +34-954-48-87-52
}

Received: 22 June 2017; Accepted: 16 July 2017; Published: 31 July 2017

\begin{abstract}
Agriculture is one of the economic sectors that affect climate change contributing to greenhouse gas emissions directly and indirectly. There is a trend of agricultural greenhouse gas emissions reduction, but any practice in this direction should not affect negatively farm productivity and economics because this would limit its implementation, due to the high global food and feed demand and the competitive environment in this sector. Precision agriculture practices using high-tech equipment has the ability to reduce agricultural inputs by site-specific applications, as it better target inputs to spatial and temporal needs of the fields, which can result in lower greenhouse gas emissions. Precision agriculture can also have a positive impact on farm productivity and economics, as it provides higher or equal yields with lower production cost than conventional practices. In this work, precision agriculture technologies that have the potential to mitigate greenhouse gas emissions are presented providing a short description of the technology and the impacts that have been reported in literature on greenhouse gases reduction and the associated impacts on farm productivity and economics. The technologies presented span all agricultural practices, including variable rate sowing/planting, fertilizing, spraying, weeding and irrigation.
\end{abstract}

Keywords: precision agriculture technologies; greenhouse gas emissions; farm productivity; variable rate nutrient application; variable rate irrigation; variable rate pesticide application; variable rate planting/seeding; precision physical weeding

\section{Introduction}

Agriculture is liable for climate change as its activities accounts for nearly $13.5 \%$ of the total global anthropogenic Greenhouse Gas (GHG) emissions [1]. During the last decade, there is a trend of GHG emissions reduction in the agricultural sector, but more effort on this direction should be made to fulfil global climate commitments. The main contribution of agriculture to GHG emissions is related to cropland soil, enteric fermentation and manure management [2]. 
The application of precision agriculture (PA) practices, using the large reservoir of Precision Agriculture Technologies (PATs) in agricultural field operations could positively contribute to GHG emission reduction due to: (i) the enhancement of the ability of soils to operate as carbon stock reserve [2] by less tillage [3] and reduced nitrogen fertilization [4,5]; (ii) the reduction of fuel consumption through less in-field operations with the tractor (direct GHG decrease); and (iii) the reduction of inputs for the agricultural field operations (indirect GHG decrease) [6]. On the other hand, these practices affect farm productivity by optimizing agricultural inputs producing higher or equal yields with lower cost than conventional practices. Therefore, GHG mitigation measures that refer to new technologies and techniques on all agricultural practices (precision/variable rate sowing/planting, fertilizing, spraying and irrigation) can reduce significantly the amount of inputs that are responsible for GHG contribution and could help on the goal of minimum climate change impact of agriculture, always taking into account that crop production should be maintained or even increased in the challenge of ensuring food security and safety for human food consumption.

Current use of PA practices in the world and EU basis is in general unclear. There was a strong uptake of PATs during the 1990s in North America, mainly because of the rise of information technology and the fact that US and Canadian agriculture had the appropriate characteristics to promote new technologies promising better economic results. Those characteristics were: (i) the large farm sizes; (ii) the organised extension system mainly by the government and universities; (iii) the farmers/entrepreneurs willingness for progress and technology adoption; (iv) the high income; (v) the possibility of financing investment; and (vi) the limited or absent subsidies in agricultural products $[7,8]$. PA growth rate flattened during the first years of 2000s, because the results (productivity increase, inputs and fuel use reduction, ease of use, low maintenance, and compatibility between brands) were not as positive as expected by the agricultural community. However, PATs are currently taking up again, because technology problems have been gradually resolved and more tangible economic results have been shown at farm level (e.g., profit increase). In 2014, PA global market already amounted to $€ 2.3$ billion, with an expected annual growth rate of $12 \%$ through 2020 with the mature US and European markets considered the most promising $[9,10]$.

However, most practitioners do not have a clear perspective of the benefits of PATs in agricultural production and do not consider the environmental reimbursements that their use could provide [11-14]. There is a need to produce evidence of the actual impact of these technologies on GHG emissions, farm productivity and economics. Therefore, the objective of this paper was to identify and describe the PATs that possess the capacity to have positive impact on GHG emissions produced from the agricultural sector in combination with farm productivity and income sustenance or improvement.

In the first section, the main sources of GHG emissions in the agricultural sector are described, while the second section analyses the GHG mitigation practices. Subsequently, the typology of PATs is presented to sort the PATs that have a potential direct positive impact on GHG emission mitigation combined with improved or at least stable farm productivity and economics. Then, a list of the most influencing PATs is presented with a short description of their technical characteristics and its GHG emissions impacts. It should be noted that literature on PATs impact on GHG emissions is highly limited and therefore the discussion on the mitigation capacity is mainly based on the reduction of agricultural inputs (e.g., fertilisers, pesticides, fuel, and water) that can be achieved using PATs. Subsequently, the farm productivity and economic impacts of acquiring and using PATs are analysed and discussed. Finally, a conclusion of the importance of PATs on both reducing GHG emissions and maintaining or increasing farm productivity and income is given.

\section{Main Sources of Agricultural GHG Emissions}

The major GHGs produced in the agricultural sector are methane $\left(\mathrm{CH}_{4}\right)$, nitrous oxide $\left(\mathrm{N}_{2} \mathrm{O}\right)$ and carbon dioxide $\left(\mathrm{CO}_{2}\right) \cdot \mathrm{CH}_{4}$ is mainly produced from the anaerobic decomposition of organic matter during enteric fermentation and manure management, but also from paddy rice cultivation; $\mathrm{N}_{2} \mathrm{O}$ arise from the microbial transformation of $\mathrm{N}$ in soils and manures (during the application of 
manure and synthetic fertiliser to land) and via urine and dung deposited by grazing animals; and $\mathrm{CO}_{2}$ arising from: (i) energy use pre-farm, on-farm and post-farm; and (ii) from changes in above and below ground carbon stocks induced by land use and land use change [15].

The agricultural sector contributes to the production of $25 \%$ of $\mathrm{CO}_{2}, 50 \%$ of $\mathrm{CH}_{4}$, and $70 \%$ of $\mathrm{N}_{2} \mathrm{O}$ emissions in a global basis summing up to nearly $13.5 \%$ of the total global anthropogenic GHG emissions, as stated above [1]. However, in OECD member countries, agriculture produces $8 \%$ of the total GHG emissions with a decline between 2000 and 2010 by an average of $0.4 \%$ per annum with simultaneous agricultural production increase of $1.6 \%$ per annum, which is interpreted into $1.97 \%$ of GHG emission intensity reduction. Therefore, the developed country members of OECD are trying to achieve synchronized GHG mitigation and productivity increase, which is the ideal situation and is defined as the "absolute decoupling" [16].

The larger agricultural economies generally produce higher levels of GHG emissions, but they do not follow the same pattern. An explanation of this statement is that, for example, France and Germany together accounted for around one third of the EU-28 agricultural GHG emissions, while the combination of the UK, Spain, Poland and Italy covered an additional third of the total. To decrease EU agriculture impact on GHG emissions, the EU Roadmap for moving to a low carbon economy recommends a reduction target of agricultural GHG emissions by $36-37 \%$ until 2030, and a more ambitious one (42-49\%) for 2050 in comparison to 1990 levels [17].

$\mathrm{N}_{2} \mathrm{O}$ is the main GHG related to agricultural soil emissions, essentially due to microbial transformation of nitrogen in the soil (the process of nitrification and denitrification to be analysed later in this paper). This concerns nitrogen mineral fertilisers, manure spreading and nitrogen from crop residues incorporated into the soil or lixiviation of surplus nitrogen. $\mathrm{N}_{2} \mathrm{O}$ has high Global Warming Potential (298 times higher than $\mathrm{CO}_{2}$ ) and it should be minimized to reduce agricultural GHG emissions in total. An example of favourable $\mathrm{N}_{2} \mathrm{O}$ emissions increase conditions is when soil temperature is increased and high moisture conditions exist during cooler months. Another example would be the increase of $\mathrm{N}_{2} \mathrm{O}$ from upland agricultural soils due to $\mathrm{CO}_{2}$ concentration [18]. The application of mineral nitrogen in the form of chemical fertilisers would also increase the $\mathrm{N}_{2} \mathrm{O}$ emissions.

Enteric fermentation, which is a natural part of the digestive process for ruminants, is the most important $\mathrm{CH}_{4}$ emission producer. $\mathrm{CH}_{4}$ is also produced during manure storage (decomposition). There are several studies targeting on $\mathrm{CH}_{4}$ measurements [19] and its mitigation potential from rice fields, mainly through water [20], fertiliser, and manure management [21]. $\mathrm{CH}_{4}$ emissions increase when mulching and organic manure are applied in soils [22]. On the other hand, midseason drainage of rice farms can reduce $\mathrm{CH}_{4}$ emissions significantly [23]. Aerobic soils may act as $\mathrm{CH}_{4}$ sinks [19,24] or emission sources [25].

As for $\mathrm{CO}_{2}$, direct combustion of hydrocarbons together with soil respiration and residual biomass decomposition are the main sources of emissions. However, the majority of the farm operations and inputs (e.g., fertilisers, pesticides, and energy) also have embodied $\mathrm{CO}_{2}$ content. Direct $\mathrm{CO}_{2}$ emissions produced by agriculture as well as indirect $\mathrm{CO}_{2}$ emissions from processing of inputs at farm level showed that this gas can represent between $10 \%$ and $20 \%$ of the total GHG emissions in agriculture [2].

\section{Greenhouse Gases Mitigation Practices}

Climate change can be mitigated through the reduction of GHG emissions, the enhancement of GHG removals and the avoidance or displacement of emissions [24]. Mismanagement of carbon (C) and nitrogen $(\mathrm{N})$ flows in the agricultural system is the reason for GHG overproduction. There are methods and technologies that reduce GHG emissions, such as the timely and accurate application of nitrogen fertilization that reduces $\mathrm{N}_{2} \mathrm{O}[26,27]$. Regarding enhancing GHG removals, any agricultural practice that increases photosynthetic processes or slows the return of stored $\mathrm{C}$ in organic biomass can be considered as C sequestration method [28]. In addition, GHG emissions can be avoided or displaced by the conversion of residual agricultural biomass into biofuel of any type [29,30], where in reality this energy source replace fossil fuels of the same energy content. 
However, the mechanisms that reduce one GHG can sometimes affect another GHG in a negative way through different mechanisms resulting in combined effects that are unknown [31,32]. For instance, no-tillage practices, which can potentially reduce GHG emissions by $20.6-23.7 \%$ compared to conventional tillage [33], may have unanticipated and unwanted effects on other sources or sinks of GHG. If, for example, soil water conservation associated with no-till were to provide more moisture for nitrifying and denitrifying bacteria as well as plants, then production of $\mathrm{N}_{2} \mathrm{O}$ might increase, offsetting some or all of the mitigation potential of carbon storage [34].

Smith et al. (2008) [24] listed the GHG emissions mitigation measures in seven categories that include different practices: (i) cropland management (nutrient management, tillage/residue management, water management, rise management, agroforestry, set-aside, and land-use change); (ii) grazing land management/pasture improvement (grazing intensity, increased productivity through fertilisation, nutrient management, fire management, and species introduction including legumes); (iii) management of organic soils (avoid drainage of wetlands); (iv) restoration of degraded lands (erosion control, organic amendments, and nutrient amendments); (v) livestock management (improved feeding practices, specific agents and dietary additives, longer term structural and management changes and animal breeding); (vi) manure/biosolid management (improved storage and handling, anaerobic digestion, and more efficient use as nutrient source); and (vii) bioenergy production (energy crops, solid, liquid, biogas, and residues).

PA for crop farming is included in the first category with a special interest on nutrient management and water management. Agricultural GHG emission mitigation should be focused on increasing the efficiency of agriculture to reduce future land conversion, and also on reducing $\mathrm{N}_{2} \mathrm{O}$ emissions from soil $\mathrm{N}$ management [35]. Eory and Moran (2012) [35] considered four mitigation measures connected with PA (improved timing of mineral nitrogen $(\mathrm{N})$ application, improved timing of organic $\mathrm{N}$ application, full allowance of manure $\mathrm{N}$ supply and avoiding $\mathrm{N}$ excess). All of them showed considerable GHG abatement potential with "Improved timing of mineral N application" reaching $0.3 \mathrm{tCO}_{2}$-eq/ha.

A report from the UK Government [36] analysing agricultural emissions in the UK reported that, to reduce national GHG emissions by $3 \mathrm{MtCO}_{2}$-eq by 2020 compared to 2007, the most promising method is nutrient management (it can reach $1.4 \mathrm{MtCO}_{2}-\mathrm{eq}$ ), followed by the use of plants with improved nitrogen use efficiency (potential of $0.8 \mathrm{MtCO}_{2}$-eq) and improved land and soil management (up to $0.45 \mathrm{MtCO}_{2}$-eq). This work shows the potential of PA practices that are directly connected with nutrient, land and soil management.

The European Commission Climate Action also proposes GHG mitigation measures related to farming practices, such as seeding/planting, harvesting, irrigation and fertilisation of existing crops, use of different varieties, diversify crops, implement management practices [37]. EU seeks for sustainable agricultural schemes through the new Common Agricultural Policy (CAP). Natural resources are depleting and agriculture has to improve its environmental performance. Sustainable management of natural resources and climate action represent one of the three main objectives of the CAP [38]. Improved sustainability will be achieved firstly by covering certain environmental requirements and obligations in order to receive full CAP funding. Secondly, from 2015 onwards, the CAP introduced a new policy instrument, the Green Direct Payment, that is granted only when there is simultaneous crop diversification, ecological focus areas and permanent grassland, with environmental benefits on biodiversity, water and soil quality, carbon sequestration and landscapes. It represents $30 \%$ of the direct payment budget and it is compulsory. Finally, rural development is vital for achieving the environmental objectives of the CAP and combating climate change, as at least $30 \%$ of the budget of each rural development programme must be reserved for targeted measures on this direction. All these policy instruments are accompanied by related training measures and other support from the Farm Advisory System, insights gained from the Innovation Partnership and applied research, which would help farmers to implement appropriate solutions for their specific situations. Proposed solutions on the farm level are the adjustment of farm operations timing; the improvement of the effectiveness of pest and disease control through better monitoring, diversified crop rotations, or integrated pest 
management methods; the use of water more efficiently by reducing water losses; improving irrigation practices; recycling or storing water; and the improvement of soil management by increasing water retention to conserve soil moisture.

PATs could participate in the achievement of agricultural sustainability as they increase the efficiency of most agricultural practices by reducing or redistributing inputs to address the real requirements of the crop. It is anticipated that the new CAP will promote further PATs as one of the methods to increase or maintain productivity with simultaneous reduction of environmental impacts, and in specific GHG emissions.

\section{Typology of Precision Agriculture Technologies}

In the literature, there are only three attempts to provide a typology of PATs. One of the most prominent studies on PA [12] classifies PATs in three main categories: Hardware and sensors (i.e., positioning and guidance, crop sensing for water stress, nutrients and yield sensing, environmental sensing, seed bed preparation, and fertiliser placement in the soil profile); Data Analysis and Decision Support Systems (i.e., protocols and standards for field data layers production, methods for data analysis for delineation of management zones, and easy-to-use software); and Commodity and whole-farm focus (i.e., development of DSS to apply commercially in farms including environmental impact assessment, and apply PA at farm level and not at field level). Zarco-Tejada et al. (2014) [14] categorised PATs for crop and livestock farming in a linear manner following the timeline of use of the technologies ending up in three categories, namely Remote sensing; Guidance systems; and Variable rate applications.

Finally, Schwarz et al. (2011) [39] have provided the most comprehensive typology of PATs (selected to be used in this work, see Figure 1), divided into three main categories: Guidance systems (i.e., hard- and software that guide tractors and implements over a field), which include all forms of automatic steering/guidance for tractors and self-propelled agricultural machinery, such as driver assistance, machine guidance, controlled traffic farming; Recording technologies (i.e., sensors mounted on ground-based stations, rolling, airborne or satellite platforms, and gathering spatial information), which include soil mapping, soil moisture mapping, canopy mapping, yield mapping, etc.; and Reacting technologies (i.e., implements, hard- and software that together can vary the placement of agricultural inputs in the field), which include technologies such as variable rate irrigation and weeding and variable rate application of seeds, fertiliser and pesticides.

Guidance technologies can be used for any agricultural practice application (including traditional practices) focusing on precise machinery movement within and between fields with tangible results in reduced overlapping causing lower input use (seeds, fertilisers, and pesticides) in parallel with decreased self-propelled machinery fuel consumption. Recording technologies are required in order to receive information from the field (before, during and after the crop period) and after processing, extract the data useful for any kind of PA application. Reacting technologies are supposed to use the data produced by the recording systems and minimize all inputs (seeds, fertilisers, pesticides, and water) in the optimum quantity required by the crop to grow. The right combination of these three categories is expected to increase or at least maintain yield with the advantage of higher quality and minimum environmental impact.

All three categories of PATs require the use of Global Navigation Satellite Systems (GNSSs), as shown in the figure. Recording technologies and GNSSs remain supportive in the PA process and they will not be analysed in the next section of this paper. Hence, reacting technologies and guidance systems were selected to be analysed and their potential to reduce GHG emissions and improve farm productivity and income was assessed. 


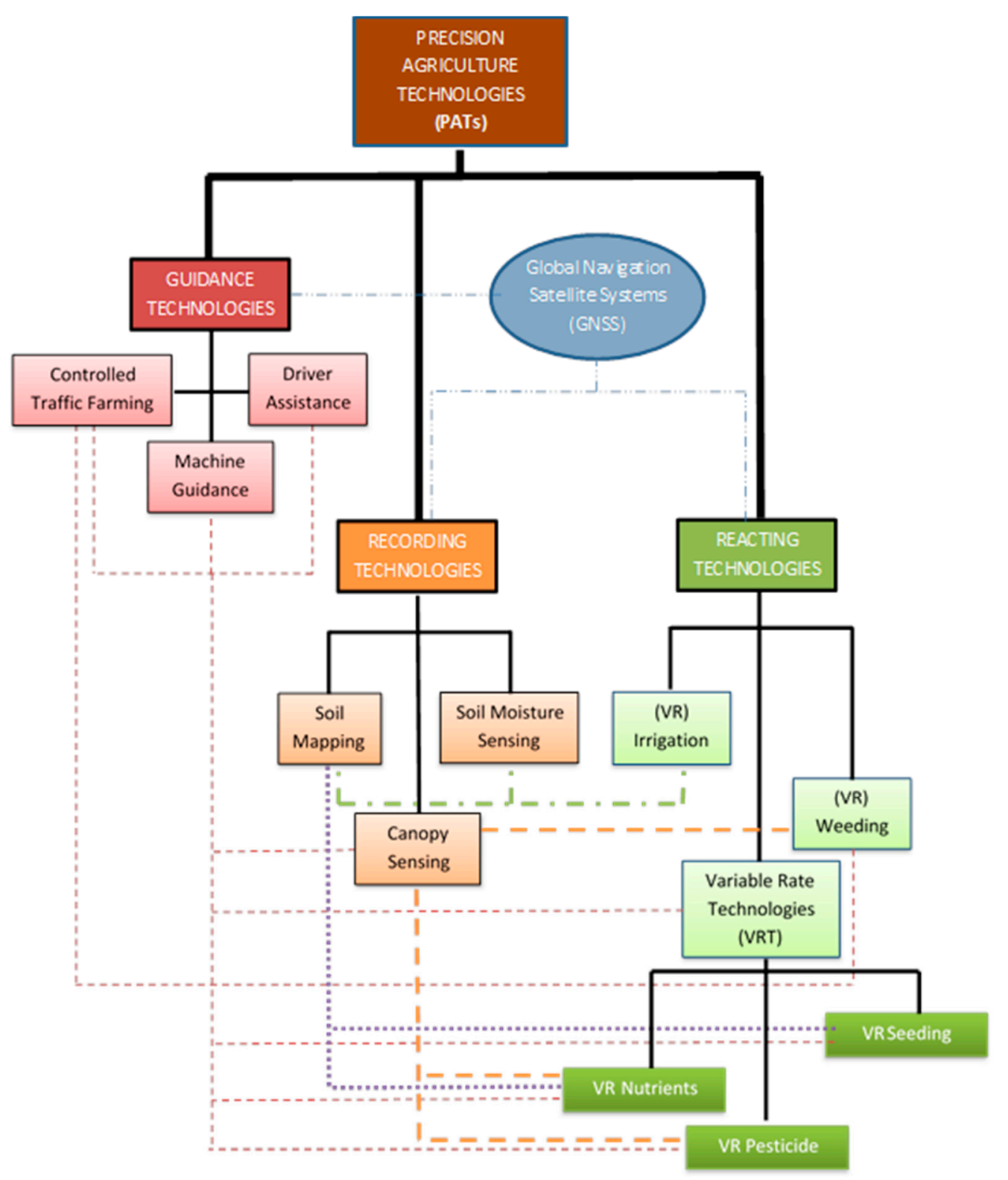

Figure 1. Precision agriculture technologies overview.

\section{Impacts of Reacting Precision Agriculture Technologies}

In this section, we present the PATs that could reduce GHG emissions and simultaneously increase/maintain farm productivity and income. At first, a short technical description of each technology is given. Then, further analysis of the GHGs emission reduction potential and its impact on farm economics and productivity is conducted.

\subsection{Variable Rate Nutrient Application (VRNA)}

\subsubsection{Description of VRNA Technologies}

Variable rate nutrient application (VRNA) can provide to the field inorganic fertilisers and manure by adjusting the mass flow rate and subsequently the application rate of nutrients according to the specific needs of the crop locally within the field. Inorganic fertiliser is either spread as liquid or solid granules, while manure is spread as slurry or solid manure. VR liquid inorganic fertiliser is spread using VR pesticide sprayer technology (mentioned later). 
VRNA is executed by either applying a prescription map that was designed after receiving data from the field using mainly canopy sensors that identify the status of the crop and correlate it with nutrient needs or by combining the recording and reacting procedure on-the-go, meaning simultaneously inorganic fertilizers are distributed in the field using two main technologies, the spinner or centrifugal spreaders that are based on a conveyer belt or chain that transfers the material (granules) from the hopper until it falls on one or more spinning disks throwing the particles into the field and the pneumatic spreaders that use airflow which divides the granules over a piped spreading boom for uniform distribution $[40,41]$. In VRNA through spinner spreaders, the application rate is controlled by adjusting the gate opening and/or changing the speed of the conveyor (and thus the input rate of material). In pneumatic applicators, VRNA is executed by spreading the material using an adjustable controlled air stream through a piped boom [42]. Liquid fertilizers (foliar or soil fertilizers) are applied using spraying machinery similarly to pesticide application (see Section 5.5.1).

As for slurry distribution in the field, the applicators work by either pressuring the slurry tank (by changing the size of the gate that brings slurry to the delivery system) or by pumping the slurry from the tank (by changing pump or valve settings). VRNA is based on changing the required slurry flowrate based on an application map or real-time soil sensors, combined with simultaneous measurements of the nitrogen content of the slurry, the ground speed and working width of the vehicle [43,44]. Solid manure spreaders work with an apron that pushes the manure towards a dispensing system $[43,44]$.

\subsubsection{GHG Emissions Reduction Potential through VRNA}

Plants require macronutrients to perform various metabolic processes. The primary macronutrients are Nitrogen $(\mathrm{N})$, Phosphorus $(\mathrm{P})$, and Potassium $(\mathrm{K})$ covering the main needs of plants to increase yield, growth and quality parameters, while the secondary macronutrients $(\mathrm{Ca}, \mathrm{Mg}$, and $\mathrm{S})$ play an auxiliary but not irrelevant role [45]. Besides this proven impact of macronutrients on plant behaviour, literature is limited on the impact of each macronutrient on GHG emissions (direct and indirect), except nitrogen that have been analysed significantly. Nitrogen fertilisation is the most significant activity producing GHG emissions in the agricultural sector, as nitrogen inorganic fertilisers are the cause of $\mathrm{CO}_{2}$ and $\mathrm{N}_{2} \mathrm{O}$ emissions during their production and $\mathrm{N}_{2} \mathrm{O}$ emissions after their application in the soil $[15,35,46-48]$.

\section{GHG Emissions from Nitrogen Fertiliser Production}

The production of fertilisers generates considerable GHG emissions being responsible for approximately $1.2 \%$ of the total global GHG emissions [47]. In order to produce $\mathrm{N}$ fertilisers, it is required to synthesize ammonia, where $\mathrm{CO}_{2}$ is produced from the use of fossil energy sources (mainly natural gas) as feedstock and fuel. Methane provides $60 \%$ of the required $\mathrm{H}_{2}$ (together with $40 \%$ from water steam) to react with atmospheric $\mathrm{N}_{2}$ and produce ammonia. A portion of $\mathrm{CH}_{4}$ is used to heat the process. On the other hand, nitric acid production process is the source of $\mathrm{N}_{2} \mathrm{O}$ emissions [46]. Ammonium nitrate (AN-N), which is the base of nitrogen fertilisers, can be produced at different levels of technology and the emitted GHGs are different in each case.

Technology advancement has decreased total GHG emissions from $7.9 \mathrm{tCO}_{2}$-eq/t AN-N to a level below $3 \mathrm{tCO}$-eq/t AN-N, which can be achieved by adopting de- $\mathrm{N}_{2} \mathrm{O}$ catalyst systems that reduce $\mathrm{N}_{2} \mathrm{O}$ emissions from nitric acid production using catalytic systems that break down $\mathrm{N}_{2} \mathrm{O}$ under high temperature into harmless nitrogen $\left(\mathrm{N}_{2}\right)$ and oxygen $\left(\mathrm{O}_{2}\right)$. These systems are being fitted to many nitric acid plants and virtually all operating plants in Europe had abatement systems since the mid-2010s. An example of the effect of de- $\mathrm{N}_{2} \mathrm{O}$ catalyst systems is the respective GHG emissions from wheat production at the economic optimum $\mathrm{N}$ fertilizer application rate that is significantly reduced by about $40 \%$, from $2.55 \mathrm{tCO}_{2}$-eq/ha to $1.6 \mathrm{tCO}_{2}$-eq/ha [46].

Therefore, if variable rate nitrogen fertilization is applied in combination with the fitting of de- $\mathrm{N}_{2} \mathrm{O}$ catalytic systems in the production line of $\mathrm{N}$ fertilizers, the result in the total GHG emissions derived by $\mathrm{N}$ application is expected to be even more positive. 


\section{GHG Emissions from Nitrogen Fertiliser Application}

Large quantities of fertilisers are being applied in agriculture forming one of the primary anthropogenic activity producing GHG emissions [48], particularly in rice cultivation [49,50]. Inorganic or organic $\mathrm{N}$ within soil is subject to various natural microbial conversion processes, some of which may produce $\mathrm{N}_{2} \mathrm{O}$. The main inorganic forms of $\mathrm{N}$ in the soil are ammonium $\left(\mathrm{NH}_{4}{ }^{+}\right)$and nitrate $\left(\mathrm{NO}_{3}{ }^{-}\right)$. Ammonium originates either directly from mineral fertilisers, from the conversion of manure or crop residues or from urea fertilisers. Nitrate is either directly applied as nitrate mineral fertiliser or results from the microbial oxidation of ammonium. Nitrate is dissolved in the water of the soil and cannot be stored in the soil over the long term. During the period of crop growth, nitrate is taken up at high rates. However, at times of low or zero crop demand, and under certain environmental conditions, nitrate can be lost either to the air via denitrification or to water by leaching. Ammonium is not mobile and most of it has to be converted into nitrate before crops can take it up. Losses of ammonium from the soil occur via volatilisation of ammonia $\left(\mathrm{NH}_{3}\right)$ [48].

Nitrification is the oxidation of ammonium to nitrate. This natural process supplies energy to the nitrifying bacteria. During the oxidation of ammonium to nitrite, $\mathrm{N}_{2} \mathrm{O}$ is produced as a by-product. Denitrification means the reduction of nitrate to di-nitrogen gas $\left(\mathrm{N}_{2}\right)$. During this process $\mathrm{N}_{2} \mathrm{O}$ is emitted to the atmosphere. The quantity of $\mathrm{N}_{2} \mathrm{O}$ released from denitrification depends on the environmental conditions-more or less $\mathrm{N}_{2} \mathrm{O}$ is produced instead of $\mathrm{N}_{2}$. The more favourable the conditions for denitrification (e.g., completely water-saturated soil), the more $\mathrm{N}_{2}$ is proportionally produced. Changing the conditions (e.g., from wet to dry soils) favours $\mathrm{N}_{2} \mathrm{O}$ release [48]. An example of the effect of nitrogen fertilisation is the allocation of the total GHG emissions from wheat when cultivated in the economic optimum $\mathrm{N}$ rate showing that almost $90 \%$ of the total GHGs are associated with $\mathrm{N}$ fertilisers $\left(\mathrm{CO}_{2}\right.$ and $\mathrm{N}_{2} \mathrm{O}$ from production and $\mathrm{N}_{2} \mathrm{O}$ from field nitrification and denitrification) [46].

A number of studies have concluded that many farmers over apply nitrogen [51-53]. According to Eurostat (2016) [54] in the period of 2005-2008 the average nitrogen surplus coming from inorganic and organic fertilizers, manure and other nitrogen inputs, such as seeds and planting material, biological fixation by leguminous crops and free living organisms, atmospheric deposition of the EU-28 member states was $51 \mathrm{~kg} \mathrm{~N} /$ ha that is an indication of the amount of nitrogen fertilisation that could be diminished in EU agricultural production. It can be that there is a trend of nitrogen surplus reduction as in the period 2009-2012 the EU-28 surplus was reduced to $48 \mathrm{~kg} \mathrm{~N} / \mathrm{ha}$.

VR fertiliser application (including manure spreading) allows for the optimum application of nitrogen according to the crop needs, reducing the final fertiliser (or manure) quantity and its associated GHG emissions both $\mathrm{CO}_{2}$ (from fuel reduction due to timely fertilization and reduced weight of the hopper) and $\mathrm{N}_{2} \mathrm{O}$ (from $\mathrm{N}$ fertiliser production and use). In the case of manure $\mathrm{CH}_{4}$ can also be decreased. GHG emissions can be further reduced when $\mathrm{N}$ fertilisation is combined with precipitation prediction or appropriate irrigation scheduling (where applicable).

Although the potential exists, there is limited data on the GHG mitigation potential of VRNA. However, there is adequate work on the impact of reducing nitrogen field applications on $\mathrm{N}_{2} \mathrm{O}$ emissions. Bates et al. (2009) [55] identified an abatement potential with VRNA of 5\% reduction in the baseline GHG emission rate that is assigned to mineral fertiliser application without yield impact. They also pointed out that there is abatement by making effective allowance for manure and residual $\mathrm{N}$ with VR technology and can reach another 5\% GHG emission reduction to the baseline emission rate for mineral fertiliser application. Millar et al. (2010) [52] found that nitrogen fertilizer application rates correlate with $\mathrm{N}_{2} \mathrm{O}$ emissions. However, the relationship between nitrogen application and $\mathrm{N}_{2} \mathrm{O}$ emissions is not necessarily linear [56,57], but the relationship of $\mathrm{N}_{2} \mathrm{O}$ emissions to nitrogen application rate increases proportionally with the application rate [27]. Another study estimated that an average of $1.19 \%$ of total nitrogen added to soils is released as $\mathrm{N}_{2} \mathrm{O}$ [58]. Babcock et al. (2004) [59] pointed out that as cropped soils emit $\mathrm{N}_{2} \mathrm{O}$ at a rate of $0.2-3 \%$ of their nitrogen inputs, when nitrogen inputs are decreased, $\mathrm{N}_{2} \mathrm{O}$ emissions could be reduced directly by approximately $1.25 \%$ of nitrogen inputs saved. 
Sehy et al. (2003) [60] examined the use of VRNA and GPS in field nitrogen application and found out that $\mathrm{N}_{2} \mathrm{O}$ emissions decreased by up to $34 \%$ in low-yielding areas.

GHG Emissions from Variable Rate Application of other Macronutrients and Lime

Literature on the impact of VR application of other macronutrients than N and lime on GHG emissions is not available, but it could be stated that VR application can affect carbon footprint indirectly because excess and/or deficit of macronutrients may change the overall growth and performance of crops.

\subsubsection{Impacts of the Use of VRNA on Productivity and Farm Economics}

Productivity and Farm Economics Impact from Variable Rate Nitrogen Fertiliser Application

Farm productivity is influenced by nitrogen fertilization rates, as it is one of the most significant parameters for increasing yield, while nitrogen constitutes an essential factor of farm economics. Sogaard and Kierkegaard (1994) [61] described the relation between nitrogen supply and plant yield with a quadratic equation. The parabolic shape reflects that each further added unit of nitrogen causes smaller yield increase of the crop. At a certain point, the benefits of an added unit of nitrogen (i.e., extra crop yield) barely outweigh the costs of this unit, and an economic optimum is reached. This economic optimum is found at lower application rates than the yield optimum. By fertilising each management zone near the economic optimum, higher returns can be achieved. Thus, the highest returns for VRNA are expected on fields with high and spatially variable nutrient requirements [62].

Excessive application of nitrogen fertilisation decreases financial returns and increases the potential for nitrogen leaching into the environment. Insufficient application can reduce yields and net farm income [53]. A landowner who benefits from fertiliser savings and yield gains through VRNA would not require additional incentives, although in case of yield losses such motivations would be needed. Additional revenue gains from VRNA could be realized with decreased need for fuel, labour, or other chemicals [63].

Several authors have analysed the impact of VRNA on farm productivity and economics. Tekin (2010) [64] estimated that VRNA can increase wheat production between 1\% and $10 \%$ offering savings in nitrogen fertilisation between $4 \%$ and $37 \%$. He also made an economic analysis using the prices of the VR equipment, the fertilisers and the price of the wheat seed and found out that the investment cost over a 5-year depreciation period would vary between $11.45 €$ and $115.39 €$ for a 500 ha and 50 ha farm size. Koch et al. (2004) [65] investigated a 18.5-ha furrow-irrigated site and a 58-ha center-pivot-irrigated site of corn fields in northeastern Colorado, USA during 2001 and 2002 concluding that nitrogen VR fertilization showed always better results than conventional application with nitrogen savings of $6-46 \%$. According to ICF (2013) [63], VR fertilisation was found to produce economic benefits through increased yields, improved crop quality, and decreased fertiliser applications. This report states that $8 \%$ increase in wheat yields (for $10 \%$ less nitrogen) and $5 \%$ increase in corn yield (for $21 \%$ less nitrogen) was shown when GreenSeeker (https: / / agriculture.trimble.com/ precision-ag/products / greenseeker/) technology was used in Maryland, USA. In Virginia, USA, using again GreenSeeker technology in corn fields resulted in nearly $27 \mathrm{~kg} /$ ha less nitrogen application than the conventional method with a nearly equivalent yield. GreenSeeker technology costs between $17,616 €$ and $19,378 €$, depending on whether farmers already have electronic flow control technology on their fertiliser application equipment. Based on the GreenSeeker price, current fertilisers prices and the reduction mentioned above from the results from Maryland, the capital cost per acre for small farms was $77.5 €$, for medium farms $35.23 €$ and for large farms $19.37 €$.

HydroSense project (2013) [66] identified a net benefit of $113 € /$ ha/year when the simpler form of precision farming was used in cotton production by using $\mathrm{N}$ sensors to estimate uniform application of fertiliser through pre-existing drip irrigation systems. A variable-rate irrigation system applied in the drip irrigation circuit resulted in a net benefit of $310 € /$ ha/year, while the net benefit climbs to 
$480 € /$ ha/year when deploying the emerging real-time and VR technology for $\mathrm{N}$ inputs even though the farmer needs to make significant investment on new equipment. It should be noted that the VR fertigation technique (fertilization + irrigation) can only be applied in crops that are irrigated using drip irrigation systems.

An experiment was conducted in four wheat fields in Oklahoma, USA in 2000 and compared to uniform fertiliser application, in-season VR application of granular fertiliser at $1 \mathrm{~m}^{2}$ spatial resolution (based on optical sensing) increased revenue (grain revenue minus fertiliser cost) by $9.69 € /$ ha when fertiliser was also applied before seeding (fixed rate) and more than $24.66 € /$ ha when fertiliser was only applied in-season [62,67]. Mamo et al. (2003) [68] executed an experiment for three years (1995, $1997,1999)$ in corn fields in rotation with sybean in Minnesota, USA and found a profit increase of 7 to $20.25 €$ /ha for corn when using VR fertilizer application compared to uniform application due to reduction in the use of fertiliser. Koch et al. (2004) [65] found an increase of 25.6 to $38.6 € /$ ha in net returns for VRNA on Colorado corn based on site-specific management zones compared to uniform application rates, both in a farmer and custom applied scenario.

Next to fertiliser costs also other costs can be attributed to VR fertiliser application, such as soil sampling or online sensing, delineation of management zones, fixed or variable costs associated with VR equipment (GPS receiver, on-board computer, software, VR system). However, the cost of these equipment or services is not only associated with VR fertiliser application and is interconnected to other PA applications. Large farm holding, due to economics of scale, allow fixed costs associated with VR equipment to be distributed over a larger area, and therefore decrease the expense of VR equipment per hectare. VR application based on grid soil sampling results to the lowest net return in comparison to the use of VR equipment, primarily due to increased fertiliser uses and soil sampling costs [65].

Managing manure as fertiliser resource for crop production can increase the return for the producer and the overall production efficiency of an animal-crop farming system in much the same way as granular fertiliser management [69]. Precision management of manure has the potential to further improve farming system production efficiency by applying the exact required manure instead of inorganic fertilizers, thus increasing the return to the farmer, as waste management becomes cheaper and the pollution potential of animal waste is minimized [70]. As with VR granular fertiliser application, the key element to VR manure application is the existence of an application map, which is laborious and time consuming to generate when acquired without sensor technology [71]. Although no literature is available considering the economic return of VR manure application, many similarities with VR granular (inorganic) fertiliser applications can be seen. The main difference is that the applied product is much bulkier, heterogeneous and lower in nutrient content and financial value [70]. It should be noted that some VR manure systems can be retrofitted to the tankers that farmers already have [44], which removes the need for large investments.

\section{Productivity and Farm Economics Impact from Variable Rate Lime Application}

Variable rate (VR) lime (which is primarily $\mathrm{CaCO}_{3}$ ) application can increase crop yields and the economic return of the farm [72]. Lime application increases the soil $\mathrm{pH}$ to a desired level and an optimal $\mathrm{pH}$ level in the soil is important to achieve optimum yields and consistent quality [73]. In addition, lime improves the uptake and availability of plant nutrients and can also improve water penetration.

VR lime application can lead to improved adjustment of soil acidity at a lower cost and with a (slightly) better yield response than uniform lime application [73]. Under-application of lime can cause large yield losses. Over-application of lime can be as detrimental as under-liming [72], as it is costly and can create problems with availability of some nutrients (for example inhibiting P and $\mathrm{Zn}$, or leading to toxic levels of $\mathrm{Mn}$ ), disease pressure, reduced herbicide performance and herbicide degradation [72,73]. Over- and under-liming cannot be avoided if lime is applied uniformly throughout 
the field. It should be noted that VR liming appears to be only profitable for high value crops, because even small effects of liming on yield produce favourable economic results in these crops [74].

The main cost in a VR lime application is the cost of grid sampling. The actual amount of lime used depends on the soil variability, field acidity, environmental factors, the sampling method and the sampling resolution [72]. Weisz et al. (2003) [72] concluded that when performing grid sampling and VR lime for 3 consecutive years in Piedmont no-till soybean fields, the net loss is $€ 11.44 /$ ha compared to uniform lime application. However, when they performed grid sampling only in year 1 and 3, and performed the VR lime in each year (with year 2 based on the PH map of year 1) this turns into a net gain of $€ 4.28 /$ ha over 3 years. Similarly, using the $\mathrm{pH}$ map from year 1 to apply lime for 3 years only in the areas were lime was initially required leads to a net gain of $€ 6.44 /$ ha estimated.

Field studies have shown that VR application of lime, as opposed to uniform application, increases soil $\mathrm{pH}$, reduces in-field variability and increases soybean yield but not corn yield [75]. In $75 \%$ of the studies (4 in total) reviewed by Lambert and Lowenberg-DeBoer (2000) [76] investigating VR lime, a positive economic effect was found, while in $25 \%$, the articles indicated mixed results. The lime application can be more effective in legumes than in corn and wheat, as the response of the latter is limited to $\mathrm{pH}$ 5-5.5, where in legumes this can go up to pH 6 [72]. Kuang et al. (2014) [73] found that VR approach in Danish spring barley can be compared to the traditional approach pointing out that the consumption of lime consumption was increased, but it was followed by an increase in yield resulting in net profit $(€ 3.61 / \mathrm{ha})$ for the VR approach compared to the traditional approach. BonGiovanni and Lowenberg-Deboer (2000) [77] also found an increase of net profit of $€ 6.51 /$ ha for Indiana corn and soybean production systems by the use of VR lime application technologies.

\subsection{Variable Rate Irrigation (VRI)}

\subsubsection{Description of VRI Technologies}

Variable rate irrigation (VRI) can either be executed using a retrofitted self-propelled irrigation systems or more recently micro-irrigation. The main types of self-propelled irrigation systems are centre pivot and linear move sprinkler systems that apply water above the canopy of the irrigated crop [78]. The most used self-propelled irrigation systems are the Mid Elevation Spray Application (MESA) with irrigation efficiency of 85\%. New developments are the Low Energy (elevation) Precision Application (LEPA) and Low Energy (elevation) Spray Application (LESA) with irrigation efficiency around $97 \%$ [79].

VRI systems are commercially available and can easily be retrofitted onto moving sprinkler systems. There are different methodologies available to deliver varying irrigation amounts along a lateral. One approach is to use parallel sprinkler control $[80,81]$ or multiple manifolds; each valved separately [82,83]. Another is to regulate the flow of water through each sprinkler drop hose by controlling the "on/off" cycle of a hydraulic valve positioned above the drop hose [84-86]. A third design changes the cross-sectional area of a sprinkler nozzle by cycling a retractable pin in and out of the nozzle in a controlled manner [87]

The most common site-specific sprinkler irrigation systems in use today are speed control systems [88]. However, zone (=boom section) control systems can achieve the same effects provided by speed control, but with greater flexibility, and provide more management options. In Europe, both centre pivot and linear move sprinkler systems are applied with a preference in the latter, in contrast to USA where centre pivot is the most common.

Micro-irrigation, a high-tech type of VRI system (drip or trickle emitters, micro-sprinkling and microspray, and subsurface irrigation), is used in areas with very scarce water supply where high value crops are installed (orchards, vineyards), as they increase crop yield, use more efficiently water, maintain warmer soil temperature and might result in less pesticide use [89]. This type of VRI is ideal for Mediterranean countries, where drip irrigation is already in extensive use due to water scarcity and such systems reduce further irrigation water use. 


\subsubsection{GHG Emission Reduction Potential through VRI}

The contribution of VRI to GHG emission abatement lies on the reduction of water, leading to lower pumping energy needs and proper irrigation scheduling preventing extreme soil water availability to boost $\mathrm{N}_{2} \mathrm{O}$ emissions.

Computer simulation studies comparing conventional and "optimized" advanced site-specific zone control by centre pivot irrigation have reported water savings of 0-26\% [88]. VRI systems can provide 8-20\% reduction in irrigation water use [90]. LaRue and Evans (2012) [91] using centre pivot speed control determined that irrigation efficiency (the ratio between irrigation water actually utilized by growing crops and water diverted from a source) can be increased by more than $5 \%$, while if speed control is also combined with zone control then the irrigation efficiency can be further improved by $14 \%$. HydroSense project [66] applied VRI in three experimental fields with cotton in Greece and showed that variable irrigation in cotton cultivation achieved 5 to $34 \%$ savings in water consumption with yield impact that was rated between $-18 \%$ and $+31 \%$. As a result, water use efficiency showed variation between $-12 \%$ and $+54 \%$. It should be noted that negative results were only shown in one field that did not affect the total positive impact of VRI. The GHG emissions linked to soil water availability depend very much on the soil type. Sandy soils will generate substantial water savings, while heavy soils will not (compared to surface irrigation systems). Lower quantities of water irrigation require lower pumping energy which, when powered by either fossil fuel motors or electricity, indirectly influence GHG emissions.

A review by Trost et al. (2013) [92] compared $\mathrm{N}_{2} \mathrm{O}$ emissions from irrigated and non-irrigated fields showing an increase of $\mathrm{N}_{2} \mathrm{O}$ emissions (about $50 \%$ to $140 \%$ ) under irrigation, in most cases studies. This shows that VRI may significantly influence $\mathrm{N}_{2} \mathrm{O}$ emission from irrigated soils. VR irrigation systems can also assist irrigation scheduling combined with meteorological prediction models and fertilization schedules in order to keep soil water availability in such levels to avoid provoking more GHG emission production through $\mathrm{N}_{2} \mathrm{O}$.

\subsubsection{Impacts of VRI Use on Productivity and Farm Economics}

VRI systems have been tested to identify their direct impact on water use reduction and indirect impact on farm productivity and economics. Few hard figures are available about the economic benefits of VRI. LaRue and Evans (2012) [91] reported that speed control in pivot irrigation systems is simply activated by changing the control unit of the system with a one-off cost of 1321-2202 $€$. However, zone control is a more complex system that can reach an investment of $10,570 €$ up to $24,663 €$. Tomasiewicz et al. (2013) [93] indicated that VRI modification of centre pivot with control system may cost between $13,212 €$ and 35,233 $€$. They also mentioned that, in 2013, 200 centre pivot systems (around $0.1 \%$ of all installed US pivots) were VRI enabled. However, it may be expected that adoption will be crop-value related: adoption will go faster in high-value crops. Threshold prices can be calculated for specific crops (e.g., for precision irrigation in the Texas High Plains, it was calculated the threshold of cotton price to be set above $1.40 € / \mathrm{kg}$ to make the use of precision irrigation profitable) [94]. Hydrosence project [66], calculated that VRI adoption in drip irrigation may cost up to $40 € /$ ha.

Lambert and Lowenberg-DeBoer (2000) [76] reported economic benefits by the use of VRI, due to higher corn yields and better water use efficiency. However, these benefits were not quantified. As mentioned above, VRI systems can add significant costs to the farm, but additional benefits have been identified by the installation of such systems, such as possible yield increase, work load reduction, water use decrease and even pesticide use saving, especially in climatic unfavourable years such as in big draughts [90,95,96]. For water use reduction, Hedley and Yule (2009) [97] tested VRI scenarios in a 156-ha pastoral farm and a 53-ha maize field in New Zealand after modelling and mapping by relating high resolution apparent electrical conductivity maps to soil available water holding capacity at two field sites. They showed significant potential water savings of 21.8 for the first site and $26.3 \%$ for the second, while these potential water savings suggest that VRI will become more affordable as irrigation costs increase. Daccache et al. (2015) [98] conducted an experiment with VRI in lettuce 
open field production in Cambridge, UK during 2012 and estimated the benefit to the grower in the reduced cost of water and energy to be typically around $30 € /$ ha to areas that are over-irrigated in humid climates. These authors also claim that the development and uptake of PI would need to be justified more in terms of the wider benefits to crop quality and reduced environmental impacts.

Currently, no economic data about VR micro-irrigation is available because VRI combined with micro-irrigation is still in its infancy.

\subsection{Machine Guidance (MG)}

\subsubsection{Description of MG Technologies}

Machine guidance refers to the applications of GNSS for steering and guidance though two main systems: driver assistance and machine auto-guidance. Driver assistance helps the driver keep his line in the field through add-ons that are not integrated in the tractor's systems and can be simply installed. The most common driver assistance system is the lightbar guidance system that consists of a horizontal series of Light Emitting Diodes (LEDs) in a plastic case in front of the operator, so he or she can see the accuracy indicator display without taking their eyes off the field. If the light is on the centreline of the lightbar, the machine is on target, while if a bar of light extends to one side, the machine is off the path and needs to be corrected. Auto-guidance is a more advanced navigation system that has the additional benefit of automatic steering of the tractor, also called auto-steering. Machine auto-guidance systems are integrated in the tractor's hydraulics and can directly take over steering operations. These more advanced systems are coupled to on-board computers that allow for headland steering, section control and that accept drive-maps (routing) and task maps to operate implements. Auto-guidance helps farmers in avoiding gaps and overlaps in multiple passes with the tractor, which is mainly caused by operator error or fatigue. It is the most adopted PAT because the impact on the farm is measurable and accurate. However, farm size matters for the technology to provide tangible results, especially in terms of environmental impact.

\subsubsection{GHG Emissions Reduction Potential through MG}

Guidance technologies improve pass-to-pass efficiency, reduce overlapping and application gaps. Guidance can be used for many field operations such as seeding, tillage, planting, weeding, and harvesting [99] and for enabling autonomous vehicles. Therefore, it is expected that all main agricultural inputs (seeds, fertiliser and pesticides) will be reduced

Guidance technology saves as standalone fuel of the self-propelled machine and inputs (fertilisers, pesticides) even if implements used are conventional type. In the case it is combined with VR application of agricultural inputs, they are also reduced further. An example is the work of Shockley et al. (2011) [100] that modelled a commercial Kentucky corn and soybean farm under no-till conditions where machine guidance during planting and fertiliser application led to cost savings of approximately $2.4 \%, 2.2 \%$ and $10.4 \%$ for seed, fertiliser and tractor fuel, respectively, which is translated to GHG emission mitigation. Guidance systems such as lightbar and auto-steering can reduce fuel consumption by $6.32 \%$ [101].

Machine guidance is based on high accuracy GNSS receivers and can be used with all kind of VR application machinery. As GNSS increases the accuracy of field applications, it will increase the reduction efficiency of the technology itself. As machine guidance is indirectly interconnected with the recording technologies, this combination is expected to reduce GHGs.

\subsubsection{Impacts of MG Use on Productivity and Farm Economics}

Guidance systems such as lightbar and auto-steering can benefit crop growers by reducing working hours as operators in the field by $6.04 \%$ and reducing fuel consumption by $6.32 \%$ [101].

In peanut digging operations, a study in Alabama during 2005-2007 growing seasons revealed average net returns between 83 and $612 € /$ ha for the use of auto-steering [102]. More particularly, they 
identified that increasing the peanut digger efficiency by accurate placement over the target rows could minimize damaged pods and yield losses. Therefore, they studied row deviation between manual driving (90-180 $\mathrm{mm}$ ) and RTK auto-steering system $(0 \mathrm{~mm})$. Data showed that for every $20 \mathrm{~mm}$ row deviation, expected yield loss was $186 \mathrm{~kg} / \mathrm{ha}$. When RTK auto-steering system was used the expected additional net returns from row deviation of $90 \mathrm{~mm}$ was 83 to $356 € /$ ha and from row deviations of $180 \mathrm{~mm}$ was 285 to $612 € /$ ha.

An experiment was conducted in south-central Alabama during 2003-2005 to evaluate how the distance of cotton row from deep tillage can affect cotton yield and economic performance and it was shown that as distance between the planted row and tillage pass increased cotton yields were reduced by $24-52 \%$ and net revenues from cotton production by $38-83 \%$. An economic analysis of farms adopting auto-guidance systems showed that systems with inaccuracies below $2.5 \mathrm{~cm}$ are most profitable for larger farms, while systems with less than $10 \mathrm{~cm}$ inaccuracy are a better economic alternative for smaller farms [103]. The accuracy level of these systems is based on the quality of differential correction and internal data processing (as the accuracy improves, the corresponding cost increases).

Farmers identify as the most frequently mentioned disadvantage of machine guidance the up-front cost [104]. Machine guidance has scalable cost according to the accuracy obtained from each system. The cost starts from $1320 €$ if a GNSS device is already held by the farmer. Commercial applicators that require a system that combine recording of all operations (to different customers) together with full navigation can reach more than $12,770 €$. A fully automatic navigation system with operator engagement only at field ends could range from 5284-44,040 €. It is important to select between simple swathing aids such as foam-marker systems that cost between $440 €$ and $2642 €$ and machine guidance systems. As a rule-of-thumb, a navigation system could cost six times more than a foam-marker system, which means that justification for GNSS navigation over foam markers must be computed from the benefit side [104].

Machine guidance can have a variety of indirect economic impacts that are due to the accurate application of different agricultural practices. For example, it is complicated to estimate the economic impact of sprayer skips, as influence of weed control on crop yield varies by crop and weed population and long-term weed seed-bank effects have to be evaluated and assessed. When a field is relatively weed-free, the skip impact to yield-loss might be minimal, but in a heavily infested field the yield may drop to almost zero in the skipped area. The most important about pesticide application gaps in economic terms is the creation of a weed seed bank all through the field that will lead to management problems and greatly increased weed control costs in future years. Another case is the impact of application gaps in fertilizer application, because skipping a part of the field is more costly in a high-value crop (fruits and vegetables) than in a bulk commodity such as corn, soybeans, or wheat [104].

\subsection{Controlled Traffic Farming (CTF)}

\subsubsection{Description of CTF Technology}

Controlled Traffic Farming is a system which confines all machinery loads to the least possible area of permanent traffic lanes. It is based on machine guidance, but it keeps record of each field and application to follow the same route every year. CTF allows optimised driving patterns, more efficient operations (i.e., reduced overlaps) and targeted input applications. It increases sustainability by reducing soil compaction and allows farming intensification as it prevents yield loss, nutrient and water efficiency reduction, soil degradation and alleviation costs.

\subsubsection{GHG Emission Reduction Potential through CTF}

CTF can reduce GHGs emissions as it affects the quantity of agricultural inputs used in field operations (fuel, fertilisers, and pesticides). A study on the potential impact of site-specific application 
and controlled traffic systems implemented on larger farms in Denmark ( 300 ha and above) has stressed how a reduction of fuel costs by $25-27 \%$ in cereals can be traced back to a lesser overlap, but also how $3-5 \%$ savings in fertiliser and pesticide in cereals can be obtained (in comparison to fertilizers and pesticides application in a conventional manner) [105]. In the same work, fuel reduction was mainly due to ease of cultivation (loose soil due to minimum compaction) and of course due to minimum overpassing. Better soil structure means that conditions will be more favourable for the absorption of GHG emissions that can be stored into the soil (e.g., $\left.\mathrm{CH}_{4}\right)$ and for prevention of harmful gases being produced through anaerobic conditions, such as $\mathrm{N}_{2} \mathrm{O}$ and $\mathrm{CH}_{4}$. The greater number and larger size of pores in a non-trafficked soil means that more water infiltrates and is captured within the profile. This means that not only there is less potential for run-off and erosion, but also that there will be more plant available water that will probably increase yield. Higher yields can be translated into increased carbon stock in the crop itself, but also will reduce GHG emission intensity as even if all agricultural inputs remain constant their ration with yield will decrease.

Tullberg (2016) [106] has analysed the impact of CTF in GHG emissions directly and indirectly, by reducing energy inputs, facilitating zero tillage and increasing fertiliser efficiency. Primarily, he referred to an approximate reduction of tractor fuel requirements of $40 \%$ and $70 \%$ while using uncontrolled traffic zero tillage and controlled traffic zero tillage farming, respectively, in comparison to conventional tillage. The CTF effect is a result of improved tractive efficiency and reduced draft at planting, reduced rolling resistance at harvest and spraying operations, and the total elimination of tillage. Then, he explained that there is no work in literature about how CTF reduce herbicide requirement, but he pointed out that there is reduction due to more timely spraying from permanent lanes and the overall mean reduction can reach $25 \%$. Fertilizers were also referred, as in CTF they are not applied to permanent wheel tracks, which is translated to fertilizer cost reduction of $10-15 \%$ for narrow-spaced crops, while yield increases by about the same amount. CTF was also mentioned to increase nitrogen efficiency (40-80\%), due to reduced soil compaction and improved soil biological activity when CTF is applied. In addition, as nitrogen fertilisers are applied at seeding time in a moist compacted seed zone with limited drainage, it is expected that denitrification is increased and as a consequence $\mathrm{N}_{2} \mathrm{O}$ will also increase. However, CTF will minimise this problem because it reduces seed zone compaction and waterlogging and allows the farmer to split fertilizer applications with denitrification reduction as a side effect. Finally, it was explained that CTF increase soil carbon stock as it reduces soil disturbance and improves the potential for cropping to mimic natural vegetation in maximising dry matter production (and water use) by double or cover cropping.

\subsubsection{Impacts of the Use of CTF on Productivity and Farm Economics}

Heavy machinery passing on soil causes damage mainly due to compaction especially in wet conditions. If traffic is reduced or stopped, soil becomes more friable, it requires little or no tillage and its structure gets better year after year. CTF reduces compaction by confining wheels or tracks to the least possible area of permanent traffic lanes. CTF is used to create and maintain healthy soils and crops in combination with sustainable farm profit. CTF typically releases $57-115 € /$ ha extra profit including the required investment, cost savings and increased yields [107]. Investment has to do with the machine guidance installed in the agricultural machinery in use (tractors, self-propelled sprayers, harvesters) and it was analysed in machine guidance section. Cost savings include improved field efficiency, less tillage and significant capital savings on machinery due to lower powered tractors needed.

Field efficiency is increased by reducing agricultural inputs and simultaneously increase yield. Using CTF can decrease fertiliser use by 10-15\% for narrow-spaced crops and pesticide reduction can reach $25 \%$ [106]. Horsch company [108] pointed out that fuel use for crop establishment with CTF is reduced by at least $35 \%$, while Jensen et al. (2012) [105] estimated that it may be possible to reduce costs of fuel by $25-27 \%$ in cereals due to less overlap. Horsch company [108] also mentioned that time and energy for crop establishment can even be reduced by $70 \%$, while it was pointed out that CTF can increase yield about $15 \%$ more (averaged across 15 crops) than randomly trafficked soils as 
a result of improved root growth that uses water and fertiliser more efficiently. According to Chamen (2016) [109], CTF is focused on the reduction of compaction, while the system in Australia already shows yield gains of $15 \%$ in sandy soils and $5 \%$ in heavier soils. The same source pointed out that a 1400 ha wheat/oilseed rape rotation farm converted from minimum tillage farming to CTF no-tillage was found to increase yield by $4 \%$ in wheat and $7.5 \%$ in oilseed rape [109].

In addition, machinery costs are reduced as lighter machines with less power are needed. Some farmers in Australia have cut their machinery costs by as much as $75 \%$, while their crop yields have risen [109]. Horsch company [108] explains that CTF planning can decrease the costs, because on the one hand existing equipment may be enough for the new farming system and on the other farmers converting to CTF can sell a lot of their equipment and invest in lower powered tractors (15\% more profit and $20 \%$ reduction in machinery costs have been recorded).

Grain research and development corporation of Australia [110] reported that the total cost for adopting CTF varies significantly from farm to farm due to farm's equipment level, ranging between $21,140 €$ and $52,850 €$. A 1400 ha wheat/oilseed rape rotation farm that converted from minimum tillage farming to CTF no tillage was examined, and it was found that farm profit was increased by $8 \%$ and the return on capital investment was $14 \%$ [109]. It was also shown that $290,000 €$ savings on machinery investment was achieved. The cost of UK consultants for providing farm survey to the farmer, including the present production constraints, the machinery and equipment requirements to apply CTF was estimated to $927 €$ plus expense and VAT. If the farmer requires a full action plan to install CTF the service cost is increased to $1390 €$ plus expense and VAT [109].

\subsection{Variable Rate Pesticide Application (VRPA)}

\subsubsection{Description of VRPA Technologies}

Variable rate pesticide application (VRPA) technologies enable changes in the application rate to match actual or potential pest stress in the field and avoid application to undesired areas of the field or plant canopies [111]. They can also be used to apply fertiliser at variable rates [112].

There are two types of VR pesticide application technology. The map-based VR pesticide application adjusts the application rate based on a prescription map, using a GPS receiver to identify the field position and the input concentration is changed as the applicator moves through the field [42]. The real-time sensor-based VR pesticide application changes the application rate using the current situation of pest stress or canopy characteristics that is identified by the difference on colour, shape, size, texture, reflectance, and temperatures of pests that is detected by different sensor types (colour cameras, photodetectors, laser scanners, multispectral and hyperspectral cameras, thermal cameras, and ultrasonic sensors). The sensor input can also be used to control the direction and rate of chemical application [111]. There are also technologies of VR pesticide application that combine sensor-based and map-based applicators to achieve higher precision (Greenseeker, Isaria, etc.). VR pesticide application technologies use other PATs (GNSS, machine guidance, crop sensing, and leaf wetness sensors) to apply the optimum pesticide quantity site-specifically. The common use of crop sensor technologies for both VR fertilizer and pesticide application is possible and can reduce cost of use.

\subsubsection{GHG Emission Reduction Potential through VRPA}

Pesticide application using variable rate technologies have the advantage of applying reduced quantities of pesticides, not exceeding the application rate indicated for the diagnosed disease (e.g., fungicides), or enemy (e.g., insecticides) or weed type (e.g., herbicide).

This means that the crop yield will not be affect negatively, as the enemy or rival will be treated at lease as efficiently as before. At the same time, the reduction of chemical application will affect the quality of the final product that could increase farm profitability due to increase product prices. 
The environmental benefits from pesticide application reduction are numerous as ground and water contamination is reduced and the influence on biodiversity becomes lower [113]. In addition, limiting insecticide use and precision application of pesticides to only infested spots, provide floral resources and shelter habitats that can increase the abundance, diversity and fitness of natural enemies, decrease pest damage, increase crop yield and the farmer's profit [114]. There is significant work on the saved pesticide quantity that ranges from 11 to $90 \%$ for herbicide use in different arable crop types [113,115-117]. Other work recorded pesticide use reduction in perennial crops between $28 \%$ and $70 \%$ [118-121]. VRPA can also cause reductions in insecticide use by $13.4 \%$ in winter wheat [122], while spray overlap can be significantly decreased with impact on the total pesticide use [123].

The impact of the high pesticide reduction shown from the literature is environmentally significant, but, in terms of GHG emission reduction, the contribution of this technology to the total agricultural effect is slight. The reason is that in this case GHG emissions are mitigated only during the industrial production of the pesticide. Even if the index of GHG emission production for every $\mathrm{kg}$ of pesticide is very high in comparison to other agricultural inputs (seed, fertilisers, and fuel), the total applied quantity is very low, mirroring a low total impact on GHGs [124].

\subsubsection{Impacts of the Use of VRPA on Productivity and Farm Economics}

Benefits of variable rate pesticide spraying are mainly associated with savings on pesticide use. Since most research has been done in the area of herbicide application (vide supra), the focus of this section lies on the economic impact of VR herbicide application.

Oriade et al. (1996) [125] suggested that weed patchiness is the most important factor economically justifying the use of site-specific weed control. Using simulation, they showed that economic and environmental benefits are almost zero at low weed pressures, particularly if weeds are evenly spread. The benefits were larger as weed populations and level of patchiness increased. At high weed patchiness, return values of $17 € /$ ha to $33 € /$ ha were found in corn and soybean. The authors concluded that returns from site-specific management of less than $14 € /$ ha are not sufficient to warrant the practice. The costs of information collection, time application effects, and human capital were not considered in this model. Beside pesticide saving, more savings are possible from shorter times per hectare for filling the tank and carrying the spray mixture to the field by reducing the volume that is needed per hectare [113].

Swinton (2003) [126] states that research results on the profitability of site-specific weed management are very variable, because certain studies focus only on potential reduced cost from less herbicide spraying, while ignoring the increased capital cost of VR application equipment and the increased variable cost of information processing. Other studies do take these last two factors into account, which results in more realistic numbers on profitability. Timmermann et al. (2003) [113] found that the monetary savings resulting from the reduction in herbicide use varied between crops, depending on the amount of herbicides saved and the price of herbicide. In maize, winter wheat, winter barley and sugar beet, savings of, respectively, $42 € /$ ha, $32 € / \mathrm{ha}, 27 € /$ ha, and $20 € /$ ha were realised. In this regard, savings also depend on the different economic thresholds for pest control and the different competitive power of the crops. Batte and Ehsani (2006) [123] estimated spray material savings of about $4 € /$ ha for a map-based spraying system compared to a self-propelled sprayer without any form of GPS for guidance assistance or sprayer control. The magnitude of input savings further increased as waterways were added to the field. Those authors also calculated the costs of the map-based spraying system, being $2911 €, 3004 €$ and $3096 €$ per year in extra costs for sprayers with a boom width of 18.3, 27.4 and 36.6 meter, respectively. Most of the costs are related to the fixed investment which diminishes per hectare as farm size increases. They also conclude that the benefits increase proportionally to the cost of the pesticide being applied, the number of annual applications, and the driver error-rate of the non-precision spraying system.

Gerhards and Sökefeld (2003) [127] evaluated the economic benefits of a real-time, automatic, site-specific weed control system compared to conventional field spraying. They found that, although 
the costs (fixed + variable) for the VR technology were larger $(9.56 € /$ ha vs. $5.20 € /$ ha), the average costs for weed control were lower due to herbicide savings ( $32 € /$ ha vs. $68 € /$ ha in winter wheat and winter barley, $69 € /$ ha vs. $148 € /$ ha in sugar beet, and $96 € /$ ha vs. $103 € /$ ha in maize). Based on these economic calculations, Dammer and Wartenberg (2007) [117] comment that, if sensors were available on the market, it would be profitable for farmers to invest in VR technologies.

Costs of map-based VRPA are attributed to mapping, data processing, decision making and site-specific application technology. Commercial mapping services typically charge $4.5-9.0 € /$ ha to map field boundaries including waterways and other physical features [123]. Gerhards and Sökefeld (2003) [127] estimated the costs of a direct injection system at $3.9 € /$ ha (in addition to the costs of the sprayer) for weed control in sugar beet, maize, winter wheat and winter barley in a German study. Batte and Ehsani (2006) [123] stated that the extra cost of a precision sprayer equipped with individually controlled nozzles based on GNSS information would be about $8000 €$. However, Timmermann et al. (2003) [113] commented that several components of VR technology, including GNSS, board computer and GIS, can also be used for other precision farming activities such as planting, fertilisation and harvest, and can therefore not be considered as a cost that is solely related to VRPA.

In contrast to map-based VRPA, an additional step of generating an application map with the help of GIS is not necessary. Therefore, there are no additional costs for computers, GIS software or DGPS. However, the sensor technology can be very expensive, although cheap sensors are available as well. Gerhards and Sökefeld (2003) [127] estimated the cost of a camera system for weed detection at $40,000 €$, whereas Dammer and Wartenberg (2007) [117] used an optoelectronic weed sensor of about $2000 €$. The latter could however not distinguish between crops and weeds and was therefore limited in its operations. In a study on maize-based cropping systems, experts within Europe evaluated that precision spraying using GPS spray maps can result in a net profit within a time frame of 3-4 years [128].

\subsection{Variable Rate Planting/Seeding (VRP/VRS)}

\subsubsection{Description}

Variable rate planting/seeding (VRP/VRS) is the method of varying the rate of plants or seeds according to local soil potential. Regular planters/seeders are based on the constant rate of plants or seeds through a ground drive wheel, while VR systems is equipped with independent gear box or hydraulic drive that is controlled according to the needs of the certain part of the field [42]. More advanced systems have independent planting/seeding elements that can also differentiate the application rate on-the-go per row [129]. A prescription map is required. VRP/VRS eliminate double planting in headlands and point rows and in very heterogeneous fields redistribute within field seeds in the optimum quantity. VRP/VRS can perform better in heterogeneous fields because seed rate differentiation will affect the yield in low crop performance zones and the final output will be in favour of the farmer.

Another technology developed in recent years is multi-hybrid planting/seeding. Machine manufacturers have started developing seeding machines that are able to seed two or more different hybrids at the same time: one high demanding and high yielding hybrid which is sown on the high performance zones of a field, while the other hybrid is a more resilient, but less yielding hybrid, which is sown on the low performance zones of the same field. The input-side of the technology is similar to the input used for VRA planters/seeders. The difference between the two technologies is found on the output side. Multi-hybrid planting/seeding needs two (or more) separate seed hoppers and an adapted seed dispensing system.

\subsubsection{GHG Emission Reduction Potential through VRP/VRS}

When applying VRP/VRS it is possible that the total plant/seed quantity used in the field will be lower (less GHG emissions coming from the production of the plant or the seed) or the same as in conventional seeding. Nevertheless, an effect of VRP/VRS on GHG emissions can be expected 
through the increased yield [130]. Another means of GHG reduction is the decreased fuel required for generating the same amount of harvest, since through VRP/VRS more harvest can be produced on a given soil surface.

\subsubsection{Impacts of the Use of VRP/VRS on Productivity and Farm Economics}

The main benefit from VRP/VRS is an increase in yield (vide infra). The main factor driving the economic performance of VRP/VRS is soil variability. In very uniform fields, the return on investment of VRP/VRS will be low, while, in heterogeneous fields with differentiated performance zones, the return on investment will be much higher. In the early years of VRP/VRS development, its economic impact was unclear.

Variable seeding rate of winter wheat can offer increase in yield from 3\% compared to uniform seeding [131]. Another research showed that farmers using variable rate seeding have achieved an average winter wheat yield benefit of $4.6 \%$ over and above farmers drilling at a flat rate. This makes the average winter wheat yield benefit over the four years of study (2011-2014) to be $6.45 \%$ [132]. Corn yields can be increased by $6 \%$ using VRS [133]. Although VRS dates back at the first years of precision agriculture movement, its importance was recently acknowledged by farmers. Specifically, $10-12 \%$ climb in acquisition of VRS drills and planters was noticed in USA in 2007 [134].

Bullock et al. (1998) [135] observed differences in economically optimal plant densities for different field qualities: they estimated that areas of the field with higher yield potential could benefit from a higher plant density. At the time, they concluded that VRS would be infeasible, because of the high cost associated with characterizing site variability. Another work stated that the investments necessary for adopting variable rate corn seeding would only be economically justifiable for farmers with some low yield potential land, where significant seeds savings and yield gains can be made, but not for farmers with a mix of solely medium and high potential land [136]. Taylor and Staggenborg (2000) [137] concluded that VRS was only economically feasible on their fields of study if less expensive ways to generate the prescription map were available or if corn showed a greater yield response to seeding rate. Shanahan et al. (2004) [138] stated that "site-specific management of plant densities may be [ed: economically] feasible", most likely due to technological advances. Dillon et al. (2009) [139] performed sensitivity analysis with respect to alternative soils, seed price, wheat price and cost of VRS technology to determine the economic feasibility of VRS and concluded that the practice of VRS of wheat in France is economically feasible. Hörbe et al. (2013) [130] performed two experiments that tested the economic returns of VRS in maize according to a prescription map with three management zones, i.e. a low crop performance zone (LZ), receiving $31 \%$ less seeds/ha, a medium crop performance zone (MZ), receiving the normal seeding rate, and a high crop performance zone (HZ) receiving $13 \%$ more seeds/ha. This resulted in a yield increase of 1.20 and 1.90 tons/ha in the LZ of the two experiments, and 0.89 and 0.94 tons / ha in the HZ. In the second experiment, carried out one year after the first, in growing season 2010-2011, this resulted to a partial net income (excluding extra costs for the VR seeder) that was around $7 \%$ higher than in the same field seeded with a flat rate over the entire field. In total, $71.5 \%$ of this higher net income was gained in the LZ, although the LZ area was smaller than the $\mathrm{HZ}$ area ( $22 \%$ vs. $28 \%$ of the total field area, respectively).

A study of automatic section control systems in VR planters among 52 fields showed a percentage of double-planted area to reach up to $15.5 \%$ and the savings from the use of VR planters ranged from 3.5 to $22.9 €$ /ha depending on the farming operation and the field type [140].

No independent scientific research on the economic impact of multi-hybrid planting/seeding is currently available, because this technology has been developed very recently. 


\subsection{Precision Physical Weeding Technology (PPW)}

\subsubsection{Description of PPW Technology}

Precision physical weeding (PPW) technology is the method of weed control through burning, mechanical weed control with knives, discs, hoes or harrows with minimum crop damage and no chemical herbicide use. The technology is still in its infancy, with some prototypes that use precise guidance and detection systems being available.

The most promising approach for weed detection is a continuous ground-based image analysis system that locate crop row in the field [141]. In this work, the design and development of an automatic machine able to perform, at the same time, mechanical and thermal weed control on maize was reported. Other detection system would be ultrasonic sensors that detect plant density that when it is increased the harrow treats this part more aggressively [142]. In this work, a system for online weed control was developed. It automatically adjusts the tine angle of a harrow and creates different levels of intensity (gentle to aggressive). A hybrid physical/chemical weeding system is mentioned by Norremark (2010) [143]. A robotic physical weeding system is applied in sugar beet that execute real-time weed infestation survey and apply four-row intra-row precision weed control implement combined with four-row precision spraying (10\% of normal herbicide dose rate). It can also combine an inter-row weed control implement that increases its efficiency.

\subsubsection{GHG emission Reduction Potential through PPW}

Precision physical weeding technology might have an effect on reducing GHG emissions through the production of the avoided pesticides. In the case of mechanical precision weeding, fuel consumption will also be reduced (and the respective GHGs) because the tractor pulling the weeding implement will confront lower draught forces coming from soil tilling when the angle of the harrow tines will be less aggressive than with the conventional tillers [142]. In the case of precision thermal weed control, the fuel for weed burning is expected to be lowered reflecting in GHG emissions in comparison to conventional weed burning implements that have continuous flame covering all field surface. However, if thermal weed control is applied in fields that the conventional weeding is based in mechanical tillage then the GHGs from burning weeds will contribute negatively in climate change. In addition, when conventional chemical weeding is substituted from precision thermal weeding, the GHG emissions coming from pesticides reduction will be partially compensated from the emissions emitted from weed burning. As in the case of VR pesticide application, the impact on the avoided GHG emissions of the total agricultural system is expected to be low.

\subsubsection{Impacts of PPW on Productivity and Farm Economics}

The hybrid mechanical/chemical system showed total estimated cost reduction for 10-year depreciation and $5 \%$ interest rate was $12 \%$ (in particular $260 € /$ ha, while conventional weeding costs $297 € /$ ha) in a 80 ha field size working 667 hours per year. When the inter-row weed control implement is added to the system, the cost reduction can reach $24 \%$. This is due to the reduction in total weed management costs compared to the conventional [143]. Peruzzi et al. (2008) [144] worked on physical weed control in open field tomatoes by applying a rolling harrow and a flaming machine in pre-transplanting together with precision hoeing in post-transplanting. It was noticed that yield increased by $15-20 \%$ due to better weed management which resulted in $400-700 €$ /ha on top of the normal harvest.

\section{Conclusions}

Climate change is a fact, and anthropogenic activities are one of the parameters accelerating the phenomenon. Through the years, agriculture did not receive great attention in terms of GHG emission production, as yield increase was the target. In the recent past, analysis of the impact of this sector on climate change has been executed and several mitigation measures were proposed. 
PA has several positive impacts on agricultural systems translated to increased farm productivity and income and recently there is significant interest on the possible GHG emission mitigation using PATs. However, literature is limited on data regarding the effect of PA on climate change. All categories of PATs (guidance, recording, and reacting) contribute to the reduction of GHG emissions due to their interconnections and it is difficult to separate them according to importance. Recording and GNSS technologies are supportive in the PA process, while reacting technologies and guidance systems have a direct visible result on the agricultural system that are applied on. Hence, these PATs were analysed according to their potential to reduce GHG emissions and improve farm productivity and income.

- Variable rate nutrient application (VRNA) technologies can reduce the fertilizer quantities applied in modern agriculture by using technology to cover site-specific nutrient needs. VRNA can be applied to all nutrient application, with nitrogen being the most important to be regulated through these technologies as it is the element that is mostly used for crop growth increase and covers the highest percentage of fertilizers globally. Therefore, VRNA can significantly contribute in accurate nutrient management, which can be translated to reduction of GHG emissions and especially nitrogen that is responsible for $\mathrm{N}_{2} \mathrm{O}$ release (the GHG derived from agricultural activities with the highest global warming potential). They can also affect positively farm productivity and income by increasing final yield especially in low productivity sections of a farm and by reducing the fertilization costs that follows optimized application of nitrogen according to the plants' needs.

- Variable rate irrigation (VRI) systems have the following GHG emission reduction potential, as its impact is dual: primarily, the decrease of irrigated water reduces the energy for water pumping, and, secondly, the optimum irrigation scheduling affect significantly the release of GHG emissions derived from fertilisers through the soil (mainly $\mathrm{N}_{2} \mathrm{O}$ ). In terms of productivity, the impact is also significant, particularly in dry areas, as irrigation scheduling kai dosage can be optimized resulting in economic benefits (lower pumping costs combined with higher yields).

- Controlled Traffic Farming (CTF) and machine guidance (MG) limit the use of tractors to only the necessary passes through the fields avoiding overlapping with respective decrease in agricultural inputs and fuel (translated into GHG emissions reduction and lower cost of production). Variable rate pesticide application (VRPA) is also expected to have GHG reduction potential by reducing the pesticide application and its industrial production. However, the actual environmental effect can be extremely significant, but through lower chemical substances application that contaminates all natural resources (water, air, and soil). The effect on farm economics is also major, especially in crops that receive many chemical applications, such as herbicides and fungicides.

- Variable rate planting/seeding (VRP/VRS) and precision physical weeding (PPW) show lower, but not irrelevant GHG emission mitigation. VRP/VRS is mainly important for optimising plant density in the field that can increase farm productivity, while the reduction in seed/plant population is associated with GHG emissions during their production. PPW reduces pesticide application and fuel used for flame burning of weeds.

It is believed that PA adoption can be increased significantly if the PATs available in the market would combine more precise and robust sensors specialised for each activity and the end-users (farmers) will receive quantified information of the farm profit augmentation and the positive sustainability impact, combined with reduced investment cost for PAT purchase. Therefore, there is a necessity that more research should be carried out on quantifying the impact of PATs on GHG emissions reduction and the respective productivity and income influence, as there is strong evidence of the contribution of PATs to climate change mitigation and the increase of production efficiency (yield and economics). Specific attention should be given to research of different macronutrients impact (direct and indirect) on GHG emissions by regulating the status of each element in crops. Optimised methods of application could maintain the amount of essential nutrients in desired quantity that will primarily reduce undesired yield loss that could be due to unknown stresses coming from unbalanced nutrient combination, and secondly will improve the carbon footprint of crops. 
Acknowledgments: The research leading to these results has received funding from the European Commission, Joint Research Centre (JRC), Directorate D. Sustainable Resources, Economics of Agriculture (service contract 199163-2015 A08-NL). This work reflects only the author's view and that the Union is not liable for any use that may be made of the information contained therein. The cost of publication in open access was covered by the European Commission.

Author Contributions: All authors conceived the idea of the paper and designed the structure: Athanasios Balafoutis, Bert Beck, Spyros Fountas, Jurgen Vangeyte and Tamme van der Wal conducted the literature review of PATs influencing GHG emissions; Athanasios Balafoutis, Bert Beck, Iria Soto, Manuel Gómez-Barbero, Andrew Barnes and Vera Eory conducted the literature review of productivity and farm economics impact of different PATs; and Spyros Fountas, Jurgen Vangeyte and Iria Soto contributed with reviewing and editing the document several times. All authors contributed in writing the paper.

Conflicts of Interest: The authors declare no conflict of interest. The founding sponsors participated in the design of the study; in the writing of the manuscript, and in the decision to publish the results.

\section{References}

1. Montzka, S.A.; Dlugokencky, E.J.; Butler, J.H. Non- $\mathrm{CO}_{2}$ greenhouse gases and climate change. Nature 2011, 476, 43-50. [CrossRef] [PubMed]

2. EU. Measures at Farm Level to Reduce Greenhouse Gas Emissions from EU Agriculture. Available online: http:/ / www.europarl.europa.eu/RegData/etudes/note/join/2014/513997/IPOL-AGRI_NT(2014) 513997_EN.pdf (accessed on 20 May 2017).

3. Angers, D.A.; Eriksen-Hamel, N.S. Full-Inversion Tillage and Organic Carbon Distribution in Soil Profiles: A Meta-Analysis. Soil Sci. Soc. Am. J. 2008, 72, 1370-1374. [CrossRef]

4. Waldrop, M.P.; Zak, D.R.; Sinsabaugh, R.L.; Gallo, M.; Lauber, C. Nitrogen deposition modifies soil carbon storage through changes in microbial enzymatic activity. Ecol. Appl. 2004, 14, 1172-1177. [CrossRef]

5. Khan, S.A.; Mulvaney, R.L.; Ellsworth, T.R.; Boast, C.W. The Myth of Nitrogen Fertilization for Soil Carbon Sequestration. J. Environ. Qual. 2007, 36, 1821-1832. [CrossRef] [PubMed]

6. Plant, R.E.; Pettygrove, G.S.; Reinert, W.R. Precision agriculture can increase profits and limit environmental impacts. Calif. Agric. 2000, 54, 66-71. [CrossRef]

7. Daberkow, S.G.; McBride, W.D. Farm and Operator Characteristics Affecting the Awareness and Adoption of Precision Agriculture Technologies in the US. Precis. Agric. 2003, 4, 163-177. [CrossRef]

8. Fountas, S.; Blackmore, S.; Ess, D.; Hawkins, S.; Blumhoff, G.; Lowenberg-Deboer, J.; Sorensen, C.G. Farmer Experience with Precision Agriculture in Denmark and the US Eastern Corn Belt. Precis. Agric. 2005, 6, 121-141. [CrossRef]

9. Sarantis, M. Europe Entering the Era of Precision Agriculture'. Available online: https://www.euractiv. $\mathrm{com} /$ section/science-policymaking/news/europe-entering-the-era-of-precision-agriculture/ (accessed on 13 March 2017).

10. Roland, B. Press Release. Available online: http://www.rolandberger.com/press_releases/market_for_ smart_agriculture_applications_growing.html (accessed on 25 May 2016).

11. Pedersen, S.M.; Fountas, S.; Blackmore, B.S.; Gylling, M.; Pedersen, J.L. Adoption and perspectives of precision farming in Denmark. Acta Agric. Scand. Sect. B 2004, 54, 2-8. [CrossRef]

12. McBratney, A.; Whelan, B.; Ancev, T.; Bouma, J. Future Directions of Precision Agriculture. Precis. Agric. 2005, 6, 7-23. [CrossRef]

13. Kutter, T.; Tiemann, S.; Siebert, R.; Fountas, S. The role of communication and co-operation in the adoption of precision farming. Precis. Agric. 2011, 12, 2-17. [CrossRef]

14. Zarco-Tejada, P.; Hubbard, N.; Loudjani, P. Precision Agriculture: An Opportunity for EU Farmers—Potential Support with the Cap 2014-2020. Available online: http:/ / www.europarl.europa.eu/RegData/etudes/note/ join/2014/529049/IPOL-AGRI_NT\%282014\%29529049_EN.pdf (accessed on 15 May 2017).

15. MacLeod, M.; Eory, V.; Gruere, G.; Lankoski, J. Cost-Effectiveness of Greenhouse Gas Mitigation Measures for Agriculture; OECD Publishing: Paris, France, 2015; Volume 89.

16. Gruère, G.; Lankoski, J. A Review of the Literature on the Cost-Effectiveness of Greenhouse Gas Mitigation Measures for Agriculture. Available online: https://www.oecd.org/officialdocuments/ publicdisplaydocumentpdf/?cote=COM/TAD /CA/ENV /EPOC(2014)44/FINAL\&docLanguage=En (accessed on 10 February 2017). 
17. A Practical Guide to a Prosperous, Low Carbon Europe. Available online: http:/ / www.roadmap2050.eu (accessed on 10 March 2017).

18. Van Groenigen, K.J.; Osenberg, C.W.; Hungate, B.A. Increased soil emissions of potent greenhouse gases under increased atmospheric $\mathrm{CO}_{2}$. Nature 2011, 475, 214-216. [CrossRef] [PubMed]

19. Le Mer, J.; Roger, P. Production, oxidation, emission and consumption of methane by soils: A review. Eur. J. Soil Biol. 2001, 37, 25-50. [CrossRef]

20. Pathak, H.; Prasad, S.; Bhatia, A.; Singh, S.; Kumar, S.; Singh, J.; Jain, M.C. Methane emission from rice-wheat cropping system in the Indo-Gangetic plain in relation to irrigation, farmyard manure and dicyandiamide application. Agric. Ecosyst. Environ. 2003, 97, 309-316. [CrossRef]

21. Linquist, B.A.; Adviento-Borbe, M.A.; Pittelkow, C.M.; van Kessel, C.; van Groenigen, K.J. Fertilizer management practices and greenhouse gas emissions from rice systems: A quantitative review and analysis. Field Crops Res. 2012, 135, 10-21. [CrossRef]

22. Ma, J.; Li, X.L.; Xu, H.; Han, Y.; Cai, Z.C.; Yagi, K. Effects of nitrogen fertiliser and wheat straw application on $\mathrm{CH} 4$ and $\mathrm{N} 2 \mathrm{O}$ emissions from a paddy rice field. Aust. J. Soil Resour. 2007, 45, 359-367. [CrossRef]

23. Zou, J.; Huang, Y.; Jiang, J.; Zheng, X.; Sass, R.L. A 3-year field measurement of methane and nitrous oxide emissions from rice paddies in China: Effects of water regime, crop residue, and fertilizer application. Glob. Biogeochem. Cycles 2005, 19. [CrossRef]

24. Smith, P.; Martino, D.; Cai, Z.; Gwary, D.; Janzen, H.; Kumar, P.; McCarl, B.; Ogle, S.; O'Mara, F.; Rice, C.; et al. Greenhouse gas mitigation in agriculture. Phil. Trans. R. Soc. B 2008, 363, 789-813. [CrossRef] [PubMed]

25. Ma, Y.C.; Kong, X.W.; Yang, B.; Zhang, X.L.; Yan, X.Y.; Yang, J.C.; Xiong, Z.Q. Net global warming potential and greenhouse gas intensity of annual rice-wheat rotations with integrated soil-crop system management. Agric. Ecosyst. Environ. 2013, 164, 209-219. [CrossRef]

26. FAO. Global Estimates of Gaseous Emissions of $\mathrm{NH}_{3}, \mathrm{NO}$ and $\mathrm{N}_{2} \mathrm{O}$ from Agricultural Land. Available online: ftp:/ / ftp.fao.org/agl/agll/docs/globest.pdf (accessed on 10 March 2017).

27. Bouwman, A.F.; Boumans, L.J.M.; Batjes, N.H. Modeling Global Annual $\mathrm{N}_{2} \mathrm{O}$ and NO Emissions from Fertilized Fields. Glob. Biogeochem. Cycles 2002, 16, 1080-1107. [CrossRef]

28. Lal, R. Soil Carbon Sequestration Impacts on Global Climate Change and Food Security. Science 2004, 304, 1623-1627. [CrossRef] [PubMed]

29. Cannell, M.G.R. Carbon sequestration and biomass energy offset: Theoretical, potential and achievable capacities globally, in Europe and the UK. Biomass Bioenergy 2003, 24, 97-116. [CrossRef]

30. Schneider, U.A.; McCarl, B.A. Economic Potential of Biomass Based Fuels for Greenhouse Gas Emission Mitigation. Environ. Resour. Econ. 2003, 24, 291-312. [CrossRef]

31. Robertson, G.P.; Grace, P.R. Greenhouse Gas Fluxes in Tropical and Temperate Agriculture: The need for a Full-Cost accounting of Global Warming Potentials. Environ. Dev. Sustain. 2004, 6, 51-63. [CrossRef]

32. Schils, R.L.M.; Verhagen, A.; Aarts, H.F.M.; Šebek, L.B.J. A farm level approach to define successful mitigation strategies for GHG emissions from ruminant livestock systems. Nutr. Cycl. Agroecosys. 2005, 71, 163-175. [CrossRef]

33. Mangalassery, S.; Sjögersten, S.; Sparkes, D.L.; Sturrock, C.J.; Craigon, J.; Mooney, S.J. To what extent can zero tillage lead to a reduction in greenhouse gas emissions from temperate soils? Sci. Rep. 2014, 4, 4586. [CrossRef] [PubMed]

34. Robertson, G.P. Keeping Track of Carbon. Science 1999, 285, 1849. [CrossRef]

35. Eory, V.; Moran, D. Review of Potential Measures for RPP2-Agriculture. Available online: http:/ / www.climatexchange.org.uk/files/3413/7338/8148/Review_of_Potential_Measures_for_RPP2_-_ Agriculture.pdf (accessed on 15 March 2017).

36. UK Government. Indicator 2: Uptake of Mitigation Methods. Available online: https://www.gov.uk/ government/uploads/system/uploads/attachment_data/file/448954/ghgindicator-2mitigation-29jul15.pdf (accessed on 15 March 2017).

37. LIFE_Environment. Climate Change Mitigation. Available online: https://ec.europa.eu/clima/sites/clima/ files/docs/climate_change_mitigation_en.pdf (accessed on 19 May 2017).

38. CAP_Reform. Overview of CAP Reform 2014-2020. Available online: https:/ /ec.europa.eu/agriculture / sites/agriculture/files/policy-perspectives/policy-briefs/05_en.pdf (accessed on 10 April 2017).

39. Schwarz, J.; Herold, L.; Pölling, B. Typology of PF Technologies; FP7 Project Future Farm. Available online: http:/ / www.futurefarm.eu/ (accessed on 24 May 2017). 
40. Behic Tekin, A.; Okyay Sındır, K. Variable Rate Control System Designed for Spinner Disc Fertiliser Spreader-“Pre Fer". Agric. Eng. 2013, 2, 45-53.

41. Hijazi, B.; Cool, S.; Vangeyte, J.; Mertens, K.; Cointault, F.; Paindavoine, M.; Pieters, J. High Speed Stereovision Setup for Position and Motion Estimation of Fertilizer Particles Leaving a Centrifugal Spreader. Sensors 2014, 14, 21466-21482. [CrossRef] [PubMed]

42. Grisso, R.; Alley, M.; Thomason, W.; Holshouser, D.; Roberson, G.T. Precision Farming Tools: Variable-Rate Application. Available online: https:/ / www.pubs.ext.vt.edu/content/dam/pubs_ext_vt_edu/442/442505/442-505_PDF.pdf (accessed on 20 March 2017).

43. Calcante, A.; Brambilla, M.; Oberti, R.; Bisaglia, C. A Retrofit Variable-Rate Control System for Pressurized Slurry Tankers. Appl. Eng. Agric. 2015, 31, 569-579.

44. Brambilla, M.; Calcante, A.; Oberti, R.; Bisaglia, C. Slurry tanker retrofitting with variable rate dosing system: A case study. In Precision Agriculture '15; Wageningen Academic Publishers: Wageningen, The Netherlands, 2015; pp. 361-368.

45. Morgan, J.; Connolly, E. Plant-soil interactions: Nutrient uptake. Nat. Educ. Knowl. 2013, 4, 2.

46. Bentrup, F.; Paliere, C. Energy Efficiency and Greenhouse gas Emissions in European Nitrogen Fertilizer Production and Use. Fertilizers Europe. Available online: http:/ /www.fertilizerseurope.com/fileadmin/ user_upload/publications/agriculture_publications/Energy_Efficiency_V9.pdf (accessed on 4 April 2017).

47. Wood, S.; Cowie, A. A Review of Greenhouse Gas Emission Factors for Fertiliser Production; For IEA Bioenergy Task 38; Orange, Research and Development Division, State Forests of New South Wales: New South Wales, Australia, 2004.

48. Schepers, J.S.; Raun, W.R. Nitrogen in Agricultural Systems; American Society of Agronomy, Crop Science Society of America, Soil Science Society of America: Madison, WI, USA, 2008.

49. Kang, N.; Jung, M.-H.; Jeong, H.-C.; Lee, Y.-S. Comparison of pooled standard deviation and standardized-t bootstrap methods for estimating uncertainty about average methane emission from rice cultivation. Atmos. Environ. 2015, 111, 39-50. [CrossRef]

50. Liu, Y.; Zhou, Z.; Zhang, X.; Xu, X.; Chen, H.; Xiong, Z. Net global warming potential and greenhouse gas intensity from the double rice system with integrated soil-crop system management: A three-year field study. Atmos. Environ. 2015, 116, 92-101. [CrossRef]

51. Bausch, W.C.; Delgado, J.A. Impact of Residual Soil Nitrate on In-Season Nitrogen Applications to Irrigated Corn Based on Remotely Sensed Assessments of Crop Nitrogen Status. Precis. Agric. 2005, 6, 509-519. [CrossRef]

52. Millar, N.; Robertson, G.P.; Grace, P.R.; Gehl, R.J.; Hoben, J.P. Nitrogen fertiliser management for nitrous oxide $\left(\mathrm{N}_{2} \mathrm{O}\right)$ mitigation in intensive corn (Maize) production: An emissions reduction protocol for US. Midwest agriculture. Mitig. Adapt. Strat. Glob. Chang. 2010, 15, 185-204. [CrossRef]

53. Ribaudo, M.; Delgado, J.; Hansen, L.; Livingston, M.; Mosheim, R.; Williamson, J. Nitrogen in Agricultural Systems: Implications for Conservation Policy. Dept. Agric. Econ. Res. Serv. 2011. [CrossRef]

54. Eurostat. Gross Nitrogen Surplus in EU 28. Available online: http://ec.europa.eu/eurostat/statisticsexplained/index.php/File:Gross_Nitrogen_Surplus,_EU-28,_CH_and_NO,_average_2005-08_vs_2009-12. png (accessed on 20 April 2017).

55. Bates, J.; Brophy, N.; Harfoot, M.; Webb, J. Sectoral Emission Reduction Potentials and Economic Costs for Climate Change (SERPEC-CC). In Agriculture: Methane and Nitrous oxide; Ecofys Netherlands: Utrecht, The Netherlands, 2009.

56. Hoben, J.P.; Gehl, R.J.; Millar, N.; Grace, P.R.; Robertson, G.P. Nonlinear nitrous oxide $\left(\mathrm{N}_{2} \mathrm{O}\right)$ response to nitrogen fertilizer in on-farm corn crops of the US Midwest. Glob. Chang. Biol. 2011, 17, 1140-1152. [CrossRef]

57. McSwiney, C.P.; Robertson, G.P. Nonlinear response of $\mathrm{N}_{2} \mathrm{O}$ flux to incremental fertilizer addition in a continuous maize (Zea mays L.) cropping system. Glob. Chang. Biol. 2005, 11, 1712-1719. [CrossRef]

58. Ogle, S.; Archibeque, S.; Gurung, R.; Paustian, K. Report on GHG Mitigation Literature Review for Agricultural Systems; US. Department of Agriculture, Climate Change Program Office: Fort Collins, CO, USA, 2010.

59. Babcock, B.A.; Paustian, K.; Hatfield, J.; Kling, C.L.; Lal, R.; McCarl, B.; McLaughlin, S.; Mosier, A.; Post, W.; Robertson, G.P.; et al. Climate Change and Greenhouse Gas Mitigation: Challenges and Opportunities for Agriculture; Council on Agricultural Science and Technology (CAST): Ames, IA, USA, 2004.

60. Sehy, U.; Ruser, R.; Munch, J.C. Nitrous oxide fluxes from maize fields: Relationship to yield, site-specific fertilization, and soil conditions. Agric. Ecosys. Environ. 2003, 99, 97-111. [CrossRef] 
61. Søgaard, H.T.; Kierkegaard, P. Yield Reduction Resulting from Uneven Fertilizer Distribution. Trans. ASAE 1994, 37, 1749-1752. [CrossRef]

62. Raun, W.R.; Solie, J.B.; Johnson, G.V.; Stone, M.L.; Lukina, E.V.; Thomason, W.E.; Schepers, J.S. In-Season Prediction of Potential Grain Yield in Winter Wheat Using Canopy Reflectance. Agron. J. 2001, 93, 131-138. [CrossRef]

63. Biggar, S.; Man, D.; Moffroid, K.; Pape, D.; Riley-Gilbert, M.; Steele, R.; Thompson, V. Greenhouse Gas Mitigation Options and Costs for Agricultural Land and Animal Production within the United States; ICF International, Department of Agriculture Climate Change Program Office: Washington, DC, USA, 2013.

64. Tekin, A.B. Variable rate fertiliser application in Turkish wheat agriculture: Economic assessment. Afr. J. Agric. Res. 2010, 5, 647-652.

65. Koch, B.; Khosla, R.; Frasier, W.M.; Westfall, D.G.; Inman, D. Economic Feasibility of Variable-Rate Nitrogen Application Utilizing Site-Specific Management Zones This study was conducted through a USDA-IFAFS-funded grant. Agron. J. 2004, 96, 1572-1580. [CrossRef]

66. HydroSence. Innovative Precision Technologies for Optimised Irrigation and Integrated Crop Management in a Water_Limited Agrosystem; LIFE+ PROJECT; LIFE08 ENV/GR/000570; Best LIFE Projects: Athens, Greece, 2013.

67. Raun, W.R.; Solie, J.B.; Johnson, G.V.; Stone, M.L.; Mullen, R.W.; Freeman, K.W.; Thomason, W.E.; Lukina, E.V. Improving Nitrogen Use Efficiency in Cereal Grain Production with Optical Sensing and Variable Rate Application. Agron. J. 2002, 94, 815-820. [CrossRef]

68. Mamo, M.; Malzer, G.L.; Mulla, D.J.; Huggins, D.R.; Strock, J. Spatial and temporal variation in economically optimum nitrogen rate for corn. Agron. J. 2003, 95, 958-964. [CrossRef]

69. Huber, D.M.; Sutton, A.L.; Jones, D.D.; Joern, B.C.; Mitchell, J.K. Nutrient management of manure to enhance crop production and protect the environment. In Proceedings of the Integrated Resource Mgt. Landscape Modifications for Environ. Protect. Conference, ASABE, Chicago, IL, USA, 13-14 December 1993.

70. Morris, D.K.; Ess, D.R.; Hawkins, S.E.; Parsons, S.D. Development of a site-specific application system for liquid animal manures. Appl. Eng. Agric. 1999, 15, 633-638. [CrossRef]

71. Schellberg, J.; Lock, R. A site-specific slurry application technique on grassland and on arable crops. Bioresour. Technol. 2009, 100, 280-286. [CrossRef] [PubMed]

72. Weisz, R.; Heiniger, R.; White, J.G.; Knox, B.; Reed, L. Long-Term Variable Rate Lime and Phosphorus Application for Piedmont No-Till Field Crops. Precis. Agric. 2003, 4, 311-330. [CrossRef]

73. Kuang, B.; Tekin, Y.; Waine, T.; Mouazen, A.M. Variable rate lime application based on on-line visible and near infrared (vis-NIR) spectroscopy measurement of soil properties in a Danish field. In Proceedings of the AgEng Conference, Zurich, Switzerland, 6-10 July 2014.

74. Swinton, S.M.; Lowenberg-DeBoer, J. Evaluating the Profitability of Site-Specific Farming. J. Produc. Agric. 1998, 11, 439-446. [CrossRef]

75. Pierce, F.J.; Warncke, D.D. Soil and crop response to variable-rate liming for two Michigan fields. Soil Sci. Soc. Am. J. 2000, 64, 774-780. [CrossRef]

76. Lambert, D.; Lowenberg-De Boer, J. Precision Agriculture Profitability Review; Purdue University: West Lafayette, IN, USA, 2000.

77. Bongiovanni, R.; Lowenberg-Deboer, J. Economics of Variable Rate Lime in Indiana. Precis. Agric. 2000, 2, 55-70. [CrossRef]

78. Berne, D. Agricultural Irrigation Initiative: Overview of Center Pivot Irrigation Systems. Available online: https:/ / neea.org/docs / default-source/reports/overview-of-center-pivot-irrigation-systems.pdf? sfvrsn=4 (accessed on 12 May 2017).

79. CSANR. Available online: http://csanr.wsu.edu/wp-content/uploads/2014/07/Peters_LEPA_2014_BIOAg. pdf (accessed on 14 May 2017).

80. McCann, I.R.; King, B.A.; Stark, J.C. Variable rate water and chemical application for continuous-move sprinkler irrigation systems. Appl. Eng. Agric. 1997, 13, 609-615. [CrossRef]

81. King, B.A.; McCann, I.R.; Eberlein, C.V.; Stark, J.C. Computer control system for spatially varied water and chemical application studies with continuous-move irrigation systems. Comput. Electon. Agric. 1999, 24, 177-194. [CrossRef]

82. Omary, M.; Camp, C.R.; Sadler, E.J. Center pivot irrigation system modification to provide variable water application depths. Appl. Eng. Agric. 1997, 13, 235-239. [CrossRef] 
83. Stone, K.C.; Sadler, E.J.; Millen, J.A.; Evans, D.E.; Camp, C.R. Water flow rates from a site-specific irrigation system. Appl. Eng. Agric. 2006, 22, 73-78. [CrossRef]

84. Dukes, M.D.; Perry, C. Uniformity testing of variable-rate center pivot irrigation control systems. Precis. Agric. 2006, 7, 205. [CrossRef]

85. Han, Y.J.; Khalilian, A.; Owino, T.O.; Farahani, H.J.; Moore, S. Development of Clemson variable-rate lateral irrigation system. Comput. Electon. Agric. 2009, 68, 108-113. [CrossRef]

86. Chávez, J.L.; Pierce, F.J.; Elliott, T.V.; Evans, R.G.; Kim, Y.; Iversen, W.M. A remote irrigation monitoring and control system (RIMCS) for continuous move systems. Part B: Field testing and results. Precis. Agric. 2010, 11, 11-26. [CrossRef]

87. King, B.A.; Kincaid, D.C. A variable flow rate sprinkler for site-specific irrigation management. Tran. ASAE 2004, 20, 765-770.

88. Evans, R.G.; LaRue, J.; Stone, K.C.; King, B.A. Adoption of site-specific variable rate sprinkler irrigation systems. Irrig. Sci. 2013, 31, 871-887. [CrossRef]

89. Camp, C.R. Subsurface drip irrigation: A review. Tran. ASAE 1998, 41, 1353-1367. [CrossRef]

90. Sadler, E.J.; Evans, R.G.; Stone, K.C.; Camp, C.R. Opportunities for conservation with precision irrigation. J. Soil Water Conserv. 2005, 60, 371-378.

91. La Rua, J.; Evans, R. Considerations for variable rate irrigation. In Proceedings of the 24th Annual Central Plains Irrigation Conference, Colby, Kansas, USA, 21-22 February 2012.

92. Trost, B.; Prochnow, A.; Drastig, K.; Meyer-Aurich, A.; Ellmer, F.; Baumecker, M. Irrigation, soil organic carbon and N2O emissions. Agron. Sustain. Dev. 2013, 33, 733-749. [CrossRef]

93. Tomasiewicz, D.J.; Hingley, L.; Derdall, E.; Vestre, B. Variable Rate Irrigation: The Next Big Thing in Irrigated Agriculture? In Proceedings of the Soils and Crops Conference, Saskatchewan, SK, Canada, 5-6 March 2013.

94. Seo, S.; Segarra, E.; Mitchell, P.D.; Leatham, D.J. Irrigation technology adoption and its implication for water conservation in the Texas High Plains: A real options approach. Agric. Econ. 2008, 38, 47-55. [CrossRef]

95. Booker, J.D.; Lascano, R.J.; Molling, C.C.; Zartman, R.E.; Acosta-Martínez, V. Temporal and spatial simulation of production-scale irrigated cotton systems. Precis. Agric. 2015, 16, 630-653. [CrossRef]

96. Evans, R.G.; King, B.A. Site-Specific Sprinkler Irrigation in a Water-Limited Future. Tran. ASABE 2012, 55, 493-504. [CrossRef]

97. Hedley, C.B.; Yule, I.J. Soil water status mapping and two variable-rate irrigation scenarios. Precis. Agric. 2009, 10, 342-355. [CrossRef]

98. Daccache, A.; Knox, J.W.; Weatherhead, E.K.; Daneshkhah, A.; Hess, T.M. Implementing precision irrigation in a humid climate - Recent experiences and on-going challenges. Agric. Water Manag. 2015, 147, 135-143. [CrossRef]

99. Abidine, A.Z.; Heidman, B.C.; Upadhyaya, S.K.; Hills, D.J. Application of RTK GPS Based Auto-Guidance System in Agricultural Production; ASABE: St. Joseph, MI, USA, 2002.

100. Shockley, J.M.; Dillon, C.R.; Stombaugh, T.S. A Whole Farm Analysis of the Influence of Auto-Steer Navigation on Net Returns, Risk, and Production Practices. J. Agric. Appl. Econ. 2015, 43, 57-75. [CrossRef]

101. Bora, G.C.; Nowatzki, J.F.; Roberts, D.C. Energy savings by adopting precision agriculture in rural USA. Energy Sustain. Soc. 2012, 2, 22. [CrossRef]

102. Ortiz, B.V.; Balkcom, K.B.; Duzy, L.; van Santen, E.; Hartzog, D.L. Evaluation of agronomic and economic benefits of using RTK-GPS-based auto-steer guidance systems for peanut digging operations. Precis. Agric. 2013, 14, 357-375. [CrossRef]

103. Bergtold, J.S.; Raper, R.L.; Schwab, E.B. The Economic Benefit of Improving the Proximity of Tillage and Planting Operations in Cotton Production with Automatic Steering. Appl. Eng. Agric. 2009, 25, 133-143. [CrossRef]

104. Grisso, R.; Alley, M.; Groover, G. Precision Farming Tools: GPS Navigation. Virginia Cooperative Extension. Available online: https:/ / pubs.ext.vt.edu/442/442-501/442-501.html (accessed on 20 May 2017).

105. Jensen, H.G.; Jacobsen, L.-B.; Pedersen, S.M.; Tavella, E. Socioeconomic impact of widespread adoption of precision farming and controlled traffic systems in Denmark. Precis. Agric. 2012, 13, 661-677. [CrossRef]

106. Tullberg, J.N. CTF and Global Warming. Available online: http://actfa.net/wp-content/uploads/2014/02/ CTF-and-Global-Warming.pdf (accessed on 20 May 2017).

107. CTF_Europe Benefits of Controlled Traffic Farming. Available online: http://www.controlledtrafficfarming. com/WhatIs/Benefits-Of-CTF.aspx (accessed on 22 May 2017). 
108. Horsch. Talking CTF. Available online: http://courteenhall.co.uk/wp-content/uploads/2015/03/H035Talking-CTF-web-2.pdf (accessed on 24 May 2017).

109. Chamen, T. Impact of Machinery on Soils and Crops. Available online: http:/ / www.controlledtrafficfarming. com/downloads/CTF-Uffington-ImpactMachinerySoilsCrops.pdf (accessed on 25 May 2017).

110. GRDC. Controlled Traffic Farming Fact Sheet. Available online: https://grdc.com.au/_data/assets/pdf_ file/0028/83872/grdcfsctflow-respdf.pdf.pdf (accessed on 27 May 2017).

111. Karkee, M.; Steward, B.; Kruckeberg, J. Automation of pesticide application systems. In Agricultural Automation, Fundamentals and Practices; Zhang, Q., Pierce, F.J., Eds.; CRC Press: Boca Raton, FL, USA, 2013.

112. Ess, D.R.; Parsons, S.D.; Case, R.M. Implementing Site-Specific Management: Sprayer Technology-Controlling Application Rate on the Go. Available online: http://www.ces.purdue.edu/extmedia/AE/SSM-5-W.pdf (accessed on 22 July 2016).

113. Timmermann, C.; Gerhards, R.; Kühbauch, W. The Economic Impact of Site-Specific Weed Control. Precis. Agric. 2003, 4, 249-260. [CrossRef]

114. Vasileiadis, V.P.; Moonen, A.C.; Sattin, M.; Otto, S.; Pons, X.; Kudsk, P.; Veres, A.; Dorner, Z.; van der Weide, R.; Marraccini, E.; et al. Sustainability of European maize-based cropping systems: Economic, environmental and social assessment of current and proposed innovative IPM-based systems. Eur. J. Agron. 2013, 48, 1-11. [CrossRef]

115. Gerhards, R.; Sökefeld, M.; Timmermann, C.; Reichart, S.; Kühbauch, W.; Williams, M.M. Results of a four-year study on site-specific herbicide application. In Proceedings of the 2nd European Conference on Precision Agriculture, Odense, Denmark, 11-15 July 1999; pp. 689-697.

116. Heisel, T.; Christensen, S.; Walter, A.M. Whole-field experiments with site-specific weed management. Proceeding of the 2nd European Conference on Precision Agriculture, Odense, Denmark, 11-15 July 1999; pp. 759-768.

117. Dammer, K.H.; Wartenberg, G. Sensor-based weed detection and application of variable herbicide rates in real time. Crop Prot. 2007, 26, 270-277. [CrossRef]

118. Solanelles, F.; Escolà, A.; Planas, S.; Rosell, J.R.; Camp, F.; Gràcia, F. An Electronic Control System for Pesticide Application Proportional to the Canopy Width of Tree Crops. Biosyst. Eng. 2006, 95, 473-481. [CrossRef]

119. Gil, E.; Escolà, A.; Rosell, J.R.; Planas, S.; Val, L. Variable rate application of plant protection products in vineyard using ultrasonic sensors. Crop Prot. 2007, 26, 1287-1297. [CrossRef]

120. Llorens, J.; Gil, E.; Llop, J.; Escolà, A. Variable rate dosing in precision viticulture: Use of electronic devices to improve application efficiency. Crop Prot. 2010, 29, 239-248. [CrossRef]

121. Chen, Y.; Ozkan, H.E.; Zhu, H.; Derksen, R.C.; Krause, C.R. Spray Deposition inside Tree Canopies from a Newly Developed Variable-Rate Air-Assisted Sprayer. Tran. ASABE 2013, 56, 1263-1272.

122. Dammer, K.-H.; Adamek, R. Sensor-Based Insecticide Spraying to Control Cereal Aphids and Preserve Lady Beetles. Agron. J. 2012, 104, 1694-1701. [CrossRef]

123. Batte, M.T.; Ehsani, M.R. The economics of precision guidance with auto-boom control for farmer-owned agricultural sprayers. Comput. Electron. Agric. 2006, 53, 28-44. [CrossRef]

124. IPCC. Climate Change 2007: The Physical Science Basis; Fourth Assessment Report; IPCC: New York, NY, USA, 2007.

125. Oriade, C.A.; King, R.P.; Forcella, F.; Gunsolus, J.L. A Bioeconomic Analysis of Site-Specific Management for Weed Control. Rev. Agric. Econ. 1996, 18, 523-535. [CrossRef]

126. Swinton, S.M. Site-specific pest management. In Pesticides_Problems, Improvements, Alternatives; den Hond, F., Groenewegen, P., van Straalen, N.M., Eds.; Oxford: England, UK, 2003; p. 155.

127. Gerhards, R.; Sökefeld, M. Precision farming in weed control—System components and economic benefits. In Precision Agric; Stafford, J.V., Werner, A., Eds.; Wageningen Academic Publishers: Wageningen, The Netherlands, 2003; pp. 229-234.

128. Vasileiadis, V.P.; Sattin, M.; Otto, S.; Veres, A.; Pálinkás, Z.; Ban, R.; Pons, X.; Kudsk, P.; van der Weide, R.; Czembor, E.; et al. Crop protection in European maize-based cropping systems: Current practices and recommendations for innovative Integrated Pest Management. Agric. Syst. 2011, 104, 533-540. [CrossRef]

129. Trimble. Available online: www.trimble.com (accessed on 18 April 2017).

130. Hörbe, T.A.N.; Amado, T.J.C.; Ferreira, A.O.; Alba, P.J. Optimization of corn plant population according to management zones in Southern Brazil. Precis. Agric. 2013, 14, 450-465. [CrossRef] 
131. Decisive_Farming. Variable Rate Seeding Benefits. Available online: http:/ /www.decisivefarming.com/ variable-rate-seeding-benefits / (accessed on 22 April 2017).

132. IPF. Under the Microscope: Variable Seed Rate Application. Available online: http:/ /www.ipf-af.com/ precision-farming/media/enews-oct14.pdf (accessed on 27 April 2017).

133. Hefty, D. Variable Rate Variety Planting in Wheat and Soybeans. AgPhD. Available online: http:/ /www. agphd.com/ag-phd-newsletter/2014/03/21/variable-rate-variety-planting-in-wheat-and-soybeans / (accessed on 3 May 2017).

134. Eric, S. Something Old: VRA Seeding \& Nitrogen. Cotton Grow. Available online: http:/ /www.cottongrower. com/crop-inputs/precision-technology/something-old-vra-seeding-nitrogen/ (accessed on 5 May 2017).

135. Bullock, D.G.; Bullock, D.S.; Nafziger, E.D.; Doerge, T.A.; Paszkiewicz, S.R.; Carter, P.R.; Peterson, T.A. Does variable rate seeding of corn pay? Agron. J. 1998, 90, 830-836. [CrossRef]

136. Lowenberg-DeBoer, J.M. Economics of Variable Rate Planting for Corn. In Proceedings of the 4th International Conference on Precision Agriculture; Lafayette: Louisiana, IN, USA, 1998; pp. 1643-1651.

137. Taylor, R.K.; Staggenborg, S. Using a GIS to Evaluate the Potential of Variable Rate Corn Seeding. In Proceedings of the ASAE Meeting Presentation, Milwaukee, WI, USA, 9-12 July 2000.

138. Shanahan, J.F.; Doerge, T.A.; Johnson, J.J.; Vigil, M.F. Feasibility of Site-Specific Management of Corn Hybrids and Plant Densities in the Great Plains. Precis. Agric. 2004, 5, 207-225. [CrossRef]

139. Dillon, C.R.; Gandonou, J.; Shockley, J. Variable rate seeding for French wheat production: Profitability and production risk management potential. In JIAC2009 Book of Abstracts; Lokhorst, C., Huijsmans, J.F.M., de Louw, R.P.M., Eds.; Wageningen Academic Publishers: Wageningen, The Netherlands, 2009; p. 350.

140. Velandia, M.; Buschermohle, M.; Larson, J.A.; Thompson, N.M.; Jernigan, B.M. The economics of automatic section control technology for planters: A case study of middle and west Tennessee farms. Comput. Electron. Agric. 2013, 95, 1-10. [CrossRef]

141. Martelloni, L. Design and Realization of an Innovative Automatic Machine Able to Perform Site-Specific Thermal Weed Control in Maize. Ph.D. Thesis, Università degli Studi di Firenze, Firenze, Italy, 2014.

142. Peteinatos, G.G.; Rueda-Ayala, R.; Gerhards, R.; Andujar, D. Precision harrowing with a flexible tine harrow and an ultrasonic sensor. In Precision Agriculture '15; Stafford, J.V., Ed.; Wageningen Academic Publishers: Wageningen, The Netherlands, 2015; pp. 579-586.

143. Norremark, M. Technologies for precision weed control. In Proceedings of the 3rd Conference of Precision crop Protection, Bonn, Germany, 19-21 September 2010.

144. Peruzzi, A.; Raffaelli, M.; Ginanni, M.; Lulli, L.; Frasconi, C.; Fontanelli, M. Innovative operative machines for physical weed control on tomato in the Serchio Valley (Central Italy). In Proceedings of the International Conference "Innovation Technology to Empower Safety, Health and Welfare in Agriculture and Agro-food Systems", Ragusa, Italy, 15-17 September 2008. 